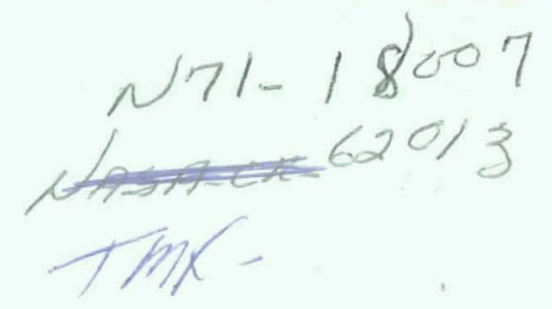

LAVA TUBES AND CHANNELS

IN THE LUNAR MARIUS HILLS

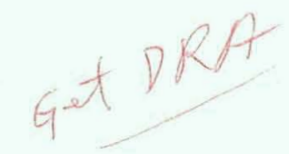

By

Ronald Greeley

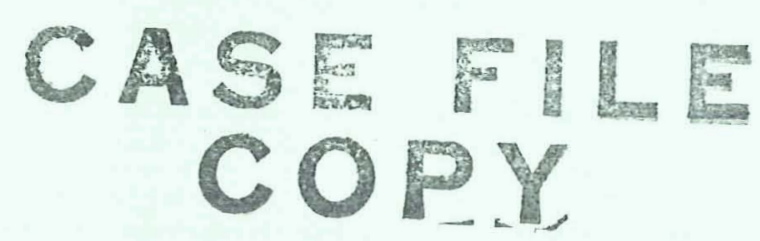

Space Sciences Division

Ames Research Center

National Aeronautics and Space Administration

Moffett Field, California 94035 


\title{
Lava Tubes and Channels \\ in the Lunar Marius Hills \\ Ronald Greeley
}

\begin{abstract}
The Marius Hills region, a volcanic plateau in Oceanus Procellarum, contains numerous rilles, rille-like structures, and chains of elongate craters. Most of these structures characteristically: 1) originate on or near irregular shaped craters associated with features previously interpreted as volcanic domes, 2) trend downslope onto Plateau Plains, 3) gene rally taper in width and become shallower, 4) are often discontinuous, 5) occupy the center, or apparent crest of a broad ridge, 6) may contain cut-off branches and distributary structures, and 7) may have local reversals in longitudinal slope. Structures having these characteristics are interpreted to be lava channels or partly collapsed lava tubes. Terrestrial lava tubes form exclusively, and commonly, in fluid basalt flows. Recent evidence indicates that viscosities of lunar mare "basalt" lava flows were conducive for lava tube formation.
\end{abstract}

Terrestrial analogs are offered for structures described in the Marius Hills. The analogs are comparable in qualitative and quantitative geomorphic aspects, excluding that of width. Scaling consideration of lunar reduced gravity accounts for increased width of the lunar structures. Linear and curvilinear rilles trending along equal elevations are interpreted to result from fracturing or faulting. 


\section{INTRODUCTION}

This paper presents quantitative and qualitative geomorphic evidence for the existence of lava channels and partly collapsed lava tubes in the Lunar Marius Hills region. Analogs are offered as terrestrial counterparts to the lunar structures described.

Marius Hills is one of several lunar areas of inferred igneous and volcanic activity. McCauley (1965) described the area as a southwarddipping volcanic plateau comprising about $35,000 \mathrm{~km}^{2}$ in the middle of Oceanus Procellarum (Figures 1 and 2). McCauley later (1967) proposed the Marius Group as new rock unit and assigned it to the Eratosthenian System. He described the area as a smooth undulating region of low, uniform albedo with prominent ridges, scarps, and local plateaus. Two types of domes (the Marius "hills") were described (Figure 2) : low domes with convex profiles and gentle slopes (2-3 degrees), and steep domes with steep concave slopes (6-7 degrees). Steep domes are often situated on low domes and both types may be elongate in a NNE-SSW orientation and have small summit pits. McCauley attributed the difference between the two dome types as possibly resulting from magmatic differentiation, with low domes as mafic and steep domes as intermediate to felsic. He also considered the possibility that they resulted from different eruptive processes with lavas of the same composition. 
Because the region offers a variety of inferred volcanic structures, Marius Hills is considered a prime Apollo landing site. Karlstrom, et al (1968) and Elston, et al (1969) presented detailed exploration plans for about $75 \mathrm{~km}^{2}$ of the Marius Hills region (Figures 2 and 7 ). They described domes of several types, ridges, endogenous craters, exogenous craters, and rilles, and proposed that many of these structures be visited, examined, photographed and sampled by the astronauts. Although they discussed possible rock types in the area and interpreted many of the structures, the rilles were somewhat neglected, though two rilles were proposed as primary investigation stations. Because rilles are prominent structures in the Marius Hills and other lunar areas and some rilles may be visited and sampled within the next few years, an understanding of rille morphology and consideration of their origin are significant to lunar geology. 


\section{RILIE DESCRIPTIONS}

Lunar rilles can be separated moxphologically into at least three types: linear rilles, sinuous rilles, and tightly meandering rilles. Linear rilles are generally large (often tens of kilometers long and more than $5 \mathrm{~km}$ wide) and appear to be controlled by deep-seated structures that cut across crater rims, mare and highland areas. Some linear rilles, however, are much smaller and may represent small faults, fractures, or fissures. Large linear rilles are probably analogous to terrestrial grabens. In contrast, sinuous rilles appear to be topographically controlled and generally trend around topographic highs. Sinuous rilles range in size from less than a few kilometers long and less than a hundred meters wide to structures exceeding tens of kilometers long. Tightly meandering rilles are charcterized by their extreme sinuosity and often resemble old age fluvial channels. The three types may grade one into another (particularly linear and sinuous rilles) and there appear to be numberous sub-types, each with a distinctive morphology. It is likely that there are several different modes of origin, each producing different types of rilles.

\section{A. Descriptive Technique}

1. Sinuosity. Meandering is a salient characteristic of sinuous rilles. Leopold and Wolman (1960) described a quantitative means of comparing sinuosity of individual channels: 


$$
S_{1}=\frac{a}{1 / 2 L}
$$

where $S_{I}=$ sinuosity, $a=$ arc length and $I=$ meander or wave length for individual segments of a channel. Thus, a straight segment would have a sinuosity of one. Overall sinuosity of a channel from end to end may be defined as:

$$
S_{2}=\frac{d_{2}}{d_{1}}
$$

where $S_{2}=$ overall sinuosity, $d_{1}=$ straight-line distance and $d_{2}$ courseline distance, end to end. A straight channel would have an overall sinuosity of one.

2. Cross sections. Cross sections perpendicular to the channel axis and longitudinal profiles aid in describing rilles. Most lunar areas lack topographic control suitable for detailed cross sections. However, the Army Topographic Command (TOPOCOM) has performed preliminary photogrammetry for the Marius Hills from stereoscopically overlapping Lunar Orbiter 5 photographs. The cross sections presented in figures 4 and 5 were prepared from TOPOCOM data. Errors in elevation, attributable to photographic resolution and inherent uncertainties in spacecraft parameters, range from $\pm 126 \mathrm{~m}$ to $\pm 162 \mathrm{~m}$ in the area considered. A manuscript topographic map (contour interval, $200 \mathrm{~m}$ ) prepared by TOPOCOM was employed for regional topography. TOPOCOM data was supplemented by height determinations from shadow measurements on steep slopes. 
3. Crater circularity. Murray and Guest (1970) showed that circularity of craters may give an indication of endogentic or exogenetic origin for craters and described several techniques for determining circularity. They noted that terrestrial impact structures and explosion craters are more circular (lower circularity index) than terrestrial endogenous craters. Circularity indexes (Method C1, Murray and Guest, 1970, p. 149-150) were obtained for the large craters in the area, including craters associated with, or at the head of, sinuous rilles. Circularity values are shown in figure 3 for Marius Hills craters and terrestrial craters. Of the terrestrial examples, all craters with a circularity index above 2 are endogenetic。

Crater circularities are not considered definitive in separating impact craters from endogenous craters. Some impact craters produced in the laboratory by projectiles fired into targets at oblique angles are noticeably noncircular (personal communication, D. E. Gault). However, when considered with other factors, circularity may aid in determining crater origin.

\section{Photographic coverage. Lunar Orbiter 5 provided photographic} coverage of the Marius Hill region with 8 stereoscopically overlapping Medium Resolution Frames (MR 210-216) at a scale of about 1:202,000 (ground resolution $\sim 2.5 \mathrm{~m}$ ). Sun angle at time of exposure, about $15.2^{\circ}$ above the horizon, is rather low and many interior crater and rille structures are in shadow。 The photographs are slightly oblique with the camera axis tilted about $10^{\circ}$ from the nadir; however, this amount is negligible in determining crater circularities. 


\section{B. Rille A.}

This rille (Figure 2), the longest channel in the area (Table 1), originates in an irregular, $2 \mathrm{~km}$ in diameter crater (circularity index $=2.59$ ) formed in Plateau Plains lava flows adjacent to a low dome (McCauley, 1968) on the east side of a prominent wrinkle ridge. Rille A passes through the ridge, trends westward downslope with the regional dip of the Marius Hills Plateau and terminates indistinctly in the mare plains. The terminal end of the channel is less than half the width of the channel at the source. Rille A can be divided into two parts, an upper sinuous section and a lower linear section.

In profile (Figure 4), the rille maintains about the same elevation as it passes through the wrinkle ridge. West of the ridge (Station I), the rille is partly buried by ejecta from Crater 1 (circularity index, 1.49) interpreted to be impact (McCauley, 1968). There is a slight depression about $4 \mathrm{~km}$ long in the floor, about midway down the rille (Station 2). The depression coincides with a segment of the channel that is sub-perpendicular to the regional topographic slope. At Station 3, the channel makes a $98^{\circ}$ turn to the south and continues downslope $15 \mathrm{~km}$ in a fairly straight course comprising the lower section. Overall slope along the rille floor is 4.3 $\mathrm{m} / \mathrm{km}\left(0^{\circ} 15^{\prime}\right)$; overall slope along the channel $\mathrm{rim}$ is $11 \mathrm{~m} / \mathrm{km}\left(0^{\circ} 38^{\prime}\right)$ 。 
TABLE 1. RILLE DIMENSIONS AND CHARACTERISTICS

\begin{tabular}{|c|c|c|c|c|c|c|c|}
\hline \multirow[b]{2}{*}{ Rille } & \multirow[b]{2}{*}{$\begin{array}{l}\text { Length } \\
\mathrm{km}\end{array}$} & \multicolumn{2}{|c|}{ Width, meters } & \multirow{2}{*}{$\begin{array}{c}\text { Depth. } \\
\text { ave. } \\
\text { meters }\end{array}$} & \multicolumn{2}{|c|}{ Sinuosity } & \multirow[b]{2}{*}{ Gradient } \\
\hline & & Max. & Min. & & $s_{1}(a v$ & $\mathrm{S}_{2}$ & \\
\hline A, total & 48.0 & 1400 & 560 & 56 & 1.21 & 1.17 & $0^{\circ} 38^{\prime}$ \\
\hline A, upper & 35.7 & 1400 & 750 & 80 & 1.21 & 1. 42 & $0^{\circ} 29^{\prime}$ \\
\hline A, lower & 12.3 & 980 & 560 & 29 & --- & 1. 08 & $1^{\circ} 08^{\prime}$ \\
\hline $\mathrm{B}$, total & 36.0 & 665 & 66 & 35 & I. 16 & I. 28 & $0^{\circ} 32^{\prime}$ \\
\hline$B$, upper & 6.8 & 665 & 415 & 95 & --- & 1.02 & $1^{\circ} 10^{\prime}$ \\
\hline$B$, lower & 29.2 & 450 & 66 & 30 & 1.16 & 1. 17 & $0^{\circ} 25^{\prime}$ \\
\hline $\mathrm{C}$ & 12.5 & 895 & 187 & 46 & --- & 1.04 & $1^{\circ} 30^{\prime}$ \\
\hline$C-1$ & 6.3 & 146 & 83 & 11 & --- & 1. 32 & $\ldots$ \\
\hline $\mathrm{D}$ & 4. 1 & 171 & $\ldots$ & 15 & 1.09 & 1. 15 &.-- \\
\hline$E$ & 0.8 & 40 & $\ldots$ & 5 & $\ldots$ & $\ldots$ & $-\cdots$ \\
\hline$F$ & 2.6 & 160 & 140 & 17 & 1.26 & 1.22 & 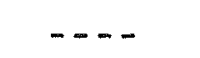 \\
\hline
\end{tabular}


Figure 5 shows cross sections perpendicular to the channel axis, constructed from photogrammetically derived elevations (TOPOCOM) and by McCauley (1968) from photodensitometer measurements obtained by the U. S. Geological Survey. Near the source (section D-D'), the channel is rather deep and has prominent levees along both sides. Downchannel at the next cross section $\left(E-E^{\prime}\right)$, the rille is centered on a ridge and the channel floor is well above the general ground level. The rille floor is flat along most of the course. However, the upper section from the source through the wrinkle ridge has a more " $V$ " shaped cross section, probably resulting from slumping of the higher channel walls.

\section{Rille B}

Rille $B$ is the second largest rille in the area (Table I) and as with Rille A, originates in Plateau Plains lava flows on the east side of the wrinkle ridge, skirts around (or crosses) the ridge, then trends northwest. The rille can be divided into two parts, an upper section on the east side of the ridge and a lower section to the west of the ridge. The upper section is fairly straight, wide, and appears to originate in an elongate cleft. The cleft has an irregular, hummocky floor and a prominent rim on the southeast side.

In profile (Figure 4) the floor of Rille B does not maintain the same elevation at the juncture with the ridge; rather, it appears to ride up and over the ridge. This may be due, in part, to slumping of the end of the 
ridge into the rille. Station 1 marks a shallow depression in the rille floor, upslope from the ridge. As the rille crosses the ridge, the channel turns abruptly northwest into the lower section. The lower section of the rille is slightly narrower than the upper section and is locally more meandering $\left(S_{1}=1.30\right.$, maximum). Station 2 marks two elongate craters in the rille floor that may be of endogenetic origin. At Station 3 the channel displays a small cut-off channel about $1.6 \mathrm{~km}$ long on the northeast side of the main channel. The subsidiary channel is about half the width of the main channel and is on a higher elevation. The lower section of Rille B trends generally downslope to Station 4 within $7 \mathrm{~km}$ of its apparent terminus. Here, the slope reverses and the rille occupies a low dome. At this same point, the rille divides into at least two small (about $180 \mathrm{~m}$ wide) channels, East Branch and West Branch, both of which become discontinuous and fade into the mare plains.

In cross section (Figure 5) many segments of Rille B occupy ridge crests or have lateral levees, similar to Rille A. In the upper section near the apparent source-cleft the rille has prominent levees (section $A-A^{\prime}$ ). Below the ridge the rille is centered on a broad topographic high (section B- $\left.\mathrm{B}^{\prime}\right)$. Near the terminus East Branch and West Branch cross a low dome (section $\mathrm{C}-\mathrm{C}^{\prime}$ ).

Walls along Rille $A$ and Rille $B$ have slumped over the channel floor. Sections of the walls exhibit boulders up to $40 \mathrm{~m}$ in diameter that have weathered from their apparent outcrop source very near the surface. 


\section{Rille C area.}

This area (Figure 6) contains at least five distinct structures: 1) a combination sinuous rille - elongate crater chain (Rille C) 2) an inferred impact crater, 3) a prominent steep dome superposed on a low dome, 4) a small sinuous rille, and 5) a small linear rille.

Rille C originates in an irregular shaped crater (circularity index = 3.76 ), about $1.66 \mathrm{~km}$ in diameter on the southeast flank of a cratered dome complex. There is no indication of a raised rim on the southeast side of the crater (the rest of the crater rim intercepts other structures) and the interior rim has a "tree bark" texture possibly resulting from soil creep. The crater floor is somewhat hummocky and has normal, round bottomed craters. One exception is a $235 \mathrm{~m}$ in diameter (largest crater on the floor) funnel, or dimple shaped crater in the northwest quadrant of the floor near the rim. Boulders up to $8 \mathrm{~m}$ in diameter have apparently weathered from the main crater rim and rolled to the bottom of the dimple crater.

Rille C leads southwest $1.45 \mathrm{~km}$ and is blocked by ejecta from Crater 2 , interpreted to be impact (circularity index, 1.38). This section of the rille is $83 \mathrm{~m}$ wide, $33 \mathrm{~m}$ deep, and has a flat floor pocked with craters up to $31 \mathrm{~m}$ in diameter. 
Southwest of the impact crater, the Rille $C$ structure continues as a series of elongate craters, identified A through $G$ beginning nearest the ejecta. Crater A has a prominent fracture extending along its southern rim forming a 100 meter-wide block that may have slumped toward the crater.

A $334 \mathrm{~m}$ in diameter crater (G), $12.5 \mathrm{~km}$ from the apparent source, is the last structure considered part of the rille system. The rille system may continue southwestward through a few elongate craters an additional $14.5 \mathrm{~km}$ to a $300 \mathrm{~m}$ wide sinuous rille. Although this small rille is on the same general trend as Rille C, there is not sufficient surface evidence to warrant its connection with Rille C.

Crater 2 is $3.12 \mathrm{~km}$ in diameter, at least $505 \mathrm{~m}$ deep, and has rims about $200 \mathrm{~m}$ about ground level. Continuous ejecta extends at least $940 \mathrm{~m}$ radially from the rim and there are no discernible ray elements. Ejecta fills part of the upper part of Rille $C$ and part of a smaller rille (Rille C-I) which may be genetically related to Rille C. Unfortunately, the crater covers the area of possible junction. Rille $\mathrm{C}-1$ is $6.25 \mathrm{~km}$ long, averages $125 \mathrm{~m}$ in width and is about $11.3 \mathrm{~m}$ deep. It is discontinuous and, like other rilles in the Marius Hills, ends by fading out on the mare surface.

The fourth structure in the area is the dome associated with the source crater of Rille C. McCauley (1968) described the dome as a compound 
structure composed of a low dome and superposed steep dome. The structure is subcircular, about $4.5 \mathrm{~km}$ in diameter, and has craters up to $270 \mathrm{~m}$ in diameter on the surface. Some craters on the dome appear to be funnel or dimple shaped; however, shadows prevent conclusive determinations of the morphology.

Cross cutting Rille $\mathrm{C}$ and the dome is a small linear rille. The rille is parallel to the major ridge system in the Marius Hills and preliminary topographic determinations indicate that the rille is nearly horizontal (paralleling the $4000 \mathrm{~m}$ contour line, Figure 6). The linear rille consists of two parts, a northern section $3.9 \mathrm{~km}$ long $\times 415 \mathrm{~m}$ wide (maximum) $\mathrm{x} 34 \mathrm{~m}$ deep (maximum) and a southern section $9.6 \mathrm{~km}$ long $\times 520 \mathrm{~m}$ wide (maximum) x $38 \mathrm{~m}$ deep. The northern section is composed of subcircular craters, some of which are connected by fractures. The structure intersects the southern rim of Rille C crater, apparently passes without surface expression across the crater floor and northern rim, and intersects the steep dome. The southern section is better defined than the northern section and is comprised of deep elongate craters and clefts connected by fractures. At the southern terminus, the rille hooks toward the southwest in a large, deep $(96 \mathrm{~m})$ elongate crater.

\section{E. Proposed Apollo Site.}

The proposed landing site (Figure 7 ) is north of Rille $B$ on relatively smooth Plateau Plains material interpreted to be lava flows and (or) pyroclastics in a small, NNW-SSE trending basin situated between domes 
(McCauley, 1968). The domes bounding the basin to the west were described by McCauley (1968) as fissure or punctured cones and interpreted to be pyroclastic deposits surrounding structurally controlled vents. There are at least three rilles in the general area, two of which (Rilles $\mathrm{D}$ and E) are scheduled as investigation stations (Elston, et al, 1969).

Rille D marks the contact between McCauley's (1968) Plateau Plains unit and the low dome on which Fissure Cone 1 is situated. The rille is at least $4.07 \mathrm{~km}$ long and $17 \mathrm{Im}$ wide. In cross section the rille is broadly rounded without a well defined wall-floor contact. Depth appears to be variable and is difficult to determine because the walls are not steep enough to cast sharp shadows. In one area, however, the rille appears to be about $15 \mathrm{~m}$ deep. Although the exact rille termini are not readily apparent, the west end is at a higher elevation than the east end and is about halfway between Fissure Cone 1 and a shallow $1.21 \mathrm{~km}$ in diameter crater.

Fissure Cone 1 is about $2.6 \mathrm{~km}$ long $\times 1.85 \mathrm{~km}$ wide and has an irregularly shaped summit depression about $1170 \mathrm{~m}$ long $\mathrm{x} 650 \mathrm{~m}$ wide x $85 \mathrm{~m}$ deep (maximum). The north end of the crater has a low rim with a broad depression trending from it north $500 \mathrm{~m}$ before hooking toward the northeast.

Rille E was described by McCauley (1968) as a 'subdued trough or rille-like depression." Similar to Rille D, it is on the dome-Plateau 
Plains contact and is scheduled as an Apollo investigation station. The rille is $790 \mathrm{~m}$ long $x 39.5 \mathrm{~m}$ wide $x$ about $5 \mathrm{~m}$ deep. It is composed of three fairly linear or curvilinear segments meeting at angles, and does not have the usual appearance of a smoothly meandering sinuous rille. The middle of the rille is at a lower elevation than the ends.

About $400 \mathrm{~m}$ northeast of Rille $\mathrm{E}$ is a series of NNW-SSE trending fractures. The fractures are about $2 \mathrm{~m}$ wide and are in discontinuous, en echelon sections, with the longest section about $1.8 \mathrm{~km}$. Although McCauley (1968) described these structures as sinuous rilles, the linear, en echelon character of the structure is not typical for sinuous rilles.

Fissure Cone 2 is in the southern sector of the proposed landing site. It is $1.6 \mathrm{~km}$ wide $\times 3.4 \mathrm{~km}$ long and has a central linear depression with a depth exceeding $135 \mathrm{~m}$ in the deepest area. The south end of the depression has a very low rim leading toward (but separated from) Rille $F$ by a gentle topographic swale about $240 \mathrm{~m}$ long. Interior and exterior walls of Fissure Cones 1 and 2 are steep and exhibit "tree bark" textures.

Rille $\mathrm{F}$ is a sinuous structure about $2.6 \mathrm{~km}$ long $\times 160 \mathrm{~m}$ wide $\times 17 \mathrm{~m}$ deep, leading downslope away from Fissure Cone 2. It tapers to about $104 \mathrm{~m}$ and becomes shallower toward the south where the rille ends nearly perpendicular to a wrinkle ridge. The wall-floor contact is better defined than in Rille $D$ and the floor in places is wide and flat. 
TERRESTRIAL ANALOGS COMPARED WITH LUNAR FEATURES

Several hypotheses on the formation of lunar sinuous rilles have been proposed in the last several years. Oberbeck, et al (1969) discussed some of the various proposals and presented evidence that at least some sinuous rilles result from collapse of lunar lava tubes; possible formation by other mechanisms, particularly that by lava channel formation, were not excluded. Morphological similarites between certain lunar rilles or rille-like structures and terrestrial lava tubes and channels are supported by recent evidence on the estimated viscosity and composition of lunar mare material. Apollo 11 and 12 mare samples closely resemble terrestrial basalt (Hess and Calio, 1969, and Anderson, et al, 1970). Laboratory simulation of molten lunar lavas by Murase and McBirney (1970) indicated that viscosity is an order of magnetitude less than the closest terrestrial counterpart and on this basis, predicted the probable existence of many large, long lunar lava tubes. Lava tubes form exclusively and commonly in basalt lava flows and it is reasonable to assume that tubes have formed in lunar basalt. Under multiple impacts at least some lunar lava tube roofs would collapse, resulting in sinuous trenches similar to collapsed terrestrial lava tubes.

\section{A. Lava tube and channel formation}

Observations of active basalt lava flows (Jagger, 1947, Finch and Macdonald, 1953) and field investigations of solidified basalt flows and lava tubes (Ollier and Brown, 1965, and Greeley and Hyde, 1970) permit speculation on lava tube and channel formation (Greeley, in press). 
Lava tubes form in fluid basalt flows that have cooled on the surface (forming a crust) with flow of fluid lava continuing beneath the crust. As cooling progresses, flow is restricted to a conduit-shaped structure within the flow. Toward the flow front, the conduit subdivides into smaller, multiple distributaries termed feeder tubes that lead molten material to the advancing flow front. As the supply of molten lava from the vent diminishes, the molten lava drains from beneath the free-standing crust and leaves a hollow void, or lava tube. Most feeder tubes do not drain, or are sealed with lava from subsequent flows. Some terrestrial lava tubes exceed $25 \mathrm{~km}$ in length and $30 \mathrm{~m}$ uncollapsed diameter.

Lava tubes occur on slopes ranging from less than $0.4^{\circ}$ to more than $6.5^{\circ}$. Basalt flows as long as $48 \mathrm{~km}$ with an overall slope of $0.61 \mathrm{~m} / \mathrm{km}$ (less than $0.1^{\circ}$ ) are known to contain lava tubes (1881 Lava Flow, Mauna Loa containing the Kaumana Lava Tube). In contrast, channels appear to form on slopes over a much wider range and develop in both viscous (aa) basalt and fluid (pahoehoe) basalt. Major lava tubes, in contrast, form only in laminar, fluid flows, possibly through shear plane development (Ollier and Brown, 1965). If flow velocity is high (as on steep slopes) or the flow is too viscous (aa basalt), then the flow may become turbulent, Iosing the shear planes, and open channels may form instead of lava tubes. Channels may also form as a result of drainage of molten lava from beneath the crust before the crust has cooled and solidified to a thickness sufficient to support its weight. The width of the channel may also exceed 
the maximum span attainable by a free standing basalt roof. In either case, the cooled or partly cooled roof collapses as the supporting fluid drains. This type of collapse often occurs in terrestrial structures and may results in sinuous channels with smooth sides or as a series of elongate drainage craters (Greeley, 1970). Thus, channels may develope in preference over tubes when 1) the gradient is steep, 2) the lava is viscous (precise limiting viscosities are not known), or 3) the crust over the molten lava is not free standing after drainage of the lava. The distinction between the tubes and channels can, thus, be made in regard to the crust: if the roof is free standing after drainage of molten lava, the structure is a tube; if the crust only partly develops, or collapses during drainage, the structure is a channel. Some structures alternate from tube to channel to tube, etc.

Active lava flows containing tubes and channels with surface crusts are closed hydrostatic systems. As an advancing flow encounters a topographic obstruction, such as a ridge, the flow may ride up and over the obstruction; the contained tube or channel may then act as a siphon operating under hydrostatic pressure to carry molten lava to the advancing flow front.

Cross sections perpendicular to lava tube axis show that lava flows often form topographic highs, or ridges, along the axis (Figure 8). Lava channels also develop topographic high regions, with the slope generally away from the axis of the structure. Lava channels are generally 
aggradational features and the channel floor is often elevated considerably higher than the surrounding ground level. This condition results from accretion of lava that spills over the bank of the channel. Multiple surges of lava, or individual flow units may spread laterally from the main channel through distributary channels or tubes (Greeley, 1969). Multiple eruptions may continue to elevate the channel and adjacent area by accretion. Tubes and possibly channels may also be erosive structures. A lava tube in southwest Washington shows areas in which the lava tube and flow apparently undercut the pre-flow valley wall (Greeley and Hyde, 1970).

Lava tubes and channels form cut-off branches along the main structure, as illustrated in figure 9. Cut-offs may be at higher, lower, or the same level as the main structure. Collapse of the roof results in an "island" surrounded by lava trenches. As collapse progressed, large blocks parallel to the tube axes may break away from the wall and slump into the collapsed tube (Figure 10).

Width of lava tubes may be fairly constant throughout their course (Hambone Lava Tube, Siskiyou Co., Calif.) or may be variable。 The trench resulting from lava tube roof collapse usually reflects the original configuration of the tube. Lava channels, on the other hand, are generally fairly constant in width; however, they may become progressively shallower. 


\section{B. Rille A.}

Rille A originates in a crater lacking raised rims and ejecta and that has a high circularity index, all indications of internal origin. Rille rims near the source (Figure 5) form prominent levees. Downslope the rille occupies the crest of a ridge at least $200 \mathrm{~m}$ above the surrounding terrain. It is unreasonable to assume that the rille eroded its channel along the center of the ridge by fluvial or nuée ardent mechanisms. Levees and ridge are considered constructional features of the rille, analogous to structures formed in association with lava channels. Although it may be argued that small levees can result from fluvial processes, an origin by water does not explain the large ridge underlying the axis of Rille $B$, reversals in slope along the channel floor (Figure 4), absence of tributaries, or tapering of channel width toward the terminus.

Morphologically, Rille $A$ is identical to many lava channels and collapsed lava tubes. Its great width probably exceeds that of a free standing lava tube roof, even under lunar conditions (Oberbeck, et al, 1969). Lava channels, however, are not restricted in width. Formation of a thin crust during active flow permits hydrostatic flow conditions and allows the structure to cross topographic highs. The ridge appears lower at the junction with Rille $A$ and the rille possibly passed through a gap, overriding small topographic obstructions. Contemporaneously, lateral channels and tubes distribute accretional lava to form levees and to elevate the overall structure. Length of Rille $A$ is comparable to terrestrial basalt flows 
containing tubes and channels. Slope along Rille $A$ is similar to that of terrestrial basalt flows (Rille $A=00^{\circ} 1^{\prime}$, Horse Cave System, Oregon= $0^{\circ} 28^{\prime}$ [Greeley, in press]).

Although quantitative and qualitative morphologic evidence and compositional evidence strongly support origin by lava channel formation, other mechanisms cannot be entirely excluded. The lower part of the rille consists of fairly straight segments which meet at rather sharp angles rather than forming meandering bends, and the rille floor is flat, suggestive of linear rilles and possible formation by block faulting.

\section{Rille B.}

The upper section of this rille, consisting of an elongate cleft and curvilinear rille, appears to be structurally controlled and may be analogous to a fissure. Figure 11 illustrates part of the Southwest Rift Zone of Mauna Loa and the associated basalt flows and channels controlled by the rift. The lower part of Rille $B$ is meandering, occupies a ridge crest, has an irregular floor, a cut-off branch at a higher elevation than the main trench, crosses a low dome, and has terminal distributary channels. These structures are best explained as parts of a collapsed lava tube network. The irregular floor and discontinuous channel (between Stations 2 and 3) may represent piles of collapsed blocks and uncollapsed sections of a lava tube roof of variable thickness, similar to that of Arnold Lava Tube, Oregon (Greeley, in press). The cut-off branch at Station 3, occupying a higher elevation than the main trench is typical for cut-off, 
subsidiary lava tubes (Figure 9). At the western terminus of Rille B, the branching and discontinuous smaller channels are analogous to feeder tubes and distributary channels frequently found in lava tubes (Figure 12). The lower section of Rille $B$, therefore, is interpreted as a nearly completely collapsed lunar lava tube. The upper section may represent a fissure zone and (or) lava channel.

\section{Rille C area.}

Rille C is a classic example of a partly collapsed lava tube. Unfortunately, precise topographic control is not available for detailed quantitative geomorphic analysis. However, preliminary topography and qualitative geomorphology provide ample evidence for its interpretation. Comparisons can be made with Giant Crater, Modoc Crater, and Mammoth Crater Lava Tubes, Northern California (Figures 13 and 14). Like these three structures, Rille $\mathrm{C}$ originates in an irregular crater (high circularity index, Figure 3) indicative of internal origin. The source craters of all the structures are situated in upland areas associated with domes (pyroclasitc cones and lava flow domes for terrestrial examples, 'extrusive structures' of McCauley [1968], for Rille C). Rille C crater has on its floor prominent funnel-shaped crater suggestive of drainage to the subsurface. Similarly, Giant Crater has internal craters (Figure 13) which resulted from subsidence and withdrawal of the magma (Anderson, I94I, p. 381). The upper channel leading from the source crater of Rille $C$ is probably similar to the elongate trough leading from Giant Crater. Both 
structures have flat floors and probably did not have free standing roofs; thus, the upper sections are considered lava channels.

Giant Crater tube passes through a series of elongate collapsed sections separated by nearly solid sections of layered and multiple basalt flows. Some solid sections have small, multiple lava tubes connecting the large collapse depressions. This configuration probably resulted from sporadic eruptions of flow and intermittant drainage of the tube. The lower end of Rille $\mathrm{C}$ also consists of a series of elongate depressions. Because the impact of Crater 2 probably generated a strong seismic wave, it is reasonable to assume that a lava tube roof within one crater diameter would be completely collapsed. However, this part of the rille is considered analogous to Giant Crater tube, with intermittant solid sections. Degradation of the rille is shown by the large slump block on the first depression. This structure is similar to collapse blocks common in many lava tubes (Figure 10).

The largest collapse depression of Rille $C$ is about $420 \mathrm{~m}$ wide, or about 3 times wider than the widest known collapsed lava tube on earth (Bear Trap Lava Tube, Idaho). Oberbeck, et al (1969) demonstrated that reduced lunar gravity would permit collapsed lunar tubes up to 500 to $1000 \mathrm{~m}$ wide, depending upon lateral slumping. Rille $C$ width is well within this range. Overall length of the rille, $12.5 \mathrm{~km}$, and estimated slope of $1.5^{\circ}$ are analogous to many terrestrial lava tubes. 
Rille C-I leading from Rille C tapers and becomes slightly shallower toward its lower end. It is discontinuous and interrupted in at least three places (Figure 6). Rille $\mathrm{C}-1$ is interpreted to be a distributary lava tube associated with the main rille. Unfortunately, Crater 2 is superposed over Rille $C$ at the juncture of the channel, collapsed tube, and the distributary channel, and it is impossible to determine the relationships between the structures. Although ejecta from the crater has altered the pre-impact topography, preliminary topography from a manuscript topographic map of the Marius Hills (TOPOCOM) indicates a slight rim along both sides of Rille C (see the $4000 \mathrm{~m}$ contour line, Figure 5).

The cross-cutting relationship of the linear rille to the mare, Rille $C$, and the dome indicates that it is younger than these features and is structurally controlled. Because the structure is nearly horizontal (parallel to the $4400 \mathrm{~m}$ contour line) it is unlikely that it resulted from fluid flow. It is interpreted to be a fault, or fault block, through which fragmental surface material has drained to form elongate craters.

\section{E. Apollo Landing Site.}

This area contains structures interpreted to be lava tubes and channels. Rilles $D$ and $F$ originate in or near cratered domes interpreted to be pyroclastic structures which are situated on low domes possibly representing flows or laccolithic structures (McCauley, 1968). These structures are analogous to Hawaiian shield volcanoes with superposed pyroclastic domes having common vents (Stearns 1966, p 45). Associated with the Hawaiian 
structure are fluid basalt flows containing lava tubes and channels. In other areas, pyroclastic cones are built from essentially the same vent as source craters for tubes and channels. Examples include Bandera Crater and lava tube, New Mexico and Deep Crater and tube, California. Deep Crater (Figure 15) is considered analogous to the fissure cone and Rille $F$ in the Apollo site.

It is difficult to determine whether Rilles $D$ and $F$ are collapsed lava tubes or are lava channels. The depth of Rille $E$ is fairly constant and the rille is continuous; thus it may not have been roofed. Rille $F$, on the other hand, is discontinuous and may represent uncollapsed, or sealed parts of a lava tube.

Rille E, composed of three linear sections, appears to traverse a slight valley, with each end at a higher elevation than the middle. Rille E and the en echelon linear depressions to the north and northeast are interpreted to be faults, fractures, or fissures. 


\section{SUMMARY AND CONCLUSIONS}

The Marius Hills region has been previously described as a volcanic province exhibiting many common volcanic structures. The mare area (Plateau Plain material of McCauley, 1968) is considered composed of volcanic flows and interbedded pyroclastics. Results from Apollo 11 , Apollo 12, and Surveyors 5 and 6 indicate the mare rocks are similar to basalts. From viscosity determinations of postulated lunar lavas, Murase and McBirney (1970) predicted the existence of many long lunar lava tubes. Lava tubes and channels are common features of terrestrial basalt flows and it is reasonable to assume that lunar lava tubes and channels exist. Under prolonged impact, many of the tube roofs would collapse, leaving sinuous trenches. The softening effect of impact would smooth surface irregularities in the trenches and channels.

Thus far, no lunar mission has yielded photographs showing structures that can be conclusively described as lunar cave entrances, although Kuiper (1965) posed some possible examples. Although to some workers, this is a criticism against the existence of lunar lava tubes, there are three points to consider: First, terrestrial lava tube entrances generally are not visible in aerial photographs. For example, Figure 16 shows a collapsed lava tube and entrance to the uncollapsed interior taken under various conditions. Figure $16 \mathrm{~A}$ is a conventional vertical photograph taken at an altitude of 30,000 feet with vertical illumination; ground resolution is $37 \mathrm{~cm}$. Figure $16 \mathrm{~B}$ is the same area, taken from an altitude of $24,000 \mathrm{ft}$, with the sun $18^{\circ}$ 
above the horizon (similar to Lunar Orbiter lighting conditions) and a ground resolution of $29 \mathrm{~cm}$. Finally, Figure $16 \mathrm{C}$ is an oblique aerial view, taken $200 \mathrm{ft}$. above ground, under good lighting conditions. Lunar Orbiter pictures, in contrast, are made at altitudes of about $370,000 \mathrm{ft}$. (Marius Hills Site) producing photographs with ground resolution of $2.5 \mathrm{~m}$ (Marius Hills photographs). If cave entrances do not show (or seldom show) in terrestrial photographs, it is unlikely that they will be visible in spacecraft photographs. Lava tubes generally begin to collapse where the roof is thinest, and where the tube tends to rise toward the surface. Collapsed roof sections often block or nearly block the entrance. Thus, lava tube entrances are considerably smaller than the uncollapsed interior. In aerial photographs the entrancessare usually lost in shadow, too small to be clearly distinguishable, or appear as irregular shadows.

Second, in many cases uncollapsed lava tubes are intermittantly blocked completely by collapse and surface detritus. The tube continues through a series of disconnected collapse depressions, none of which display cave entrances.

Third, if most mare areas are as old as Apollo 11 and 12 indicate, then lava tubes and channels would be significantly degraded. All but the deepest tubes would be collapsed, thus reducing the number of tube, or cave, entrances. 
All the structures in the Marius Hills interpreted to be lava tubes or channels originate in topographically high areas, often in or near McCauley's "steep" or "low" domes and often in irregular shaped craters. The rilles then trend downslope into the plateau plains, generally decreasing in width and depth. One has a cut off branch at a different elevation than the main channel and one rille bifurcates near its terminus. Structures for which topographic control is available are shown to be situated along or near the crest of a topographic high, or to have pronounced levees. The rille floor is well above general ground level, indicating the structures were aggradational.

Rilles $\mathrm{C}, \mathrm{F}_{s}$ and part of $\mathrm{B}$ are discontinuous and interpreted to be collapsed lava tubes. Because of its width and continuous channel, Rille A is considered to be a lava channel. It is considered to have passed through the wrinkle ridge at a relatively low region and have carried over topographic obstructions. Rille $D$ is also continuous, but is in a size class attainable by lava tubes. Its origin, whether lava tube or lava channel, is not determined. Some of the rilles, particularly Rille B, appear to have been structurally controlled by fissures and fractures.

Rille $\mathrm{E}$ and the linear rille near Rille $\mathrm{C}$ because they are straight, cut across other structures, and do not trend downslope, are considered to be faults, fractures, or fissures. They may have been modified by slumping and drainage of surface material into the subsurface. 
Although the lines of evidence presented here in support of origin by lava tube and channel formation can be applied to similar lunar structures in other areas, particularly in regions of suspected volcanic activity, it is not suggested that all sinuous rilles have formed by this mechanism. As stated previously, there appear to be many sub-types of sinuous rilles, each of which may have formed in a different way. It is also conceivable that different mechanisms could produce similar appearing structures. However, in the Marius Hills, most of the rilles appear to have resulted from lava flow activity.

\section{ACKNOW LEDGMENTS}

Grateful acknowledgment is made of $M$. Lovas for field and laboratory assistance in studies of terrestrial analogs. I wish to thank R. Reynolds and R. Wrigley for their comments and suggestions in regard to the manuscript. This study was conducted while on tenure as a National Research Council-NASA Research Associate. 


\section{REFERENCES}

Anderson, C. A., 1941: Volcanoes of the Medicine Lake Highland, Calif. Univ. Calif. Publ., Bull. Dept. Geol. Sci., v. 25, pp. 247-421.

Anderson, D. H. , et al, 1970: Preliminary examination of lunar samples from Apollo 12. Science, vo 167, pp. 1325-1339.

Elston, D. Po and C. R. Willingham, 1969: Five-day mission plan to investigate the geology of the Marius Hills Region of the Moon: Astrogeology I4 U. S。 Geol. Survey, open-file report, 55 p.

Finch, R. Ho and G. A. Macdonald, 1953: Hawaiian volcanoes during 1950. U. S. Geol. Survey, Bull. 996-B, pp. 27-89.

Greeley, R., I969: Geology and morphology of a small lava tube (abstract). EOS, Trans. Amer. Geophysical Union, Vo 50, no. II, p. 678.

Greeley, R., 1970: Terrestrial analogs to lunar dimple (drainage) craters. The Moon, v. I, pp. 237-252。

Greeley, R. and J. Hyde, 1970: Lava tubes of Mount St. Helens, Washington (abstract). Geol。Soc. Amer. Abstracts with Programs, v. 2, no. 2, pp. $96-97$.

Greeley, R. (in press): Geology and morphology of selected lava tubes in the vicinity of Bend, Oregon。 State of Oregon, Dept. of Geology and Minerail Industries. 
Hess, W. N. and Ao J. Calio, 1969: Summary of scientific results in Apollo 11 - Preliminary Science Report, NASA SP-214, pp. I-7.

Jaggar, T。 A., 1947: Origin and development of craters. Geol. Soc. Amer., Mem. 21, 508 p.

Karlstrom, T. N. V。, J. F. McCauley, and G. A. Swann, 1968: Preliminary lunar exploration plan of the Marius Hills Region of the Moon: Astrogeology 5, U. S。 Geol. Survey open-file report. 42 p.

Kuiper, G。 P., 1965: Interpretation of Ranger VII Records, in Ranger VII, Part 2, Experimenter's Analysis and Interpretations. Jet Propulsion Lab., Calif. Inst. Technol., Tech. Rept. 32-700, pp. 9-73.

Leopold, L. B., and M。 G. Wolman, I960: River meanders. Bull. Geol. Soc. Amer., v. 71 , pp. 769-794.

McCauley, J. F。, 1965: The Marius Hills volcanic complex, in Astrogeologic Studies, Ann. Prog. Rept., July 1, 1964 to July 1, 1965, pt. A: U. S. Geol. Survey open-file report, pp. I15-122.

McCauley, J. F., 1967: Geology of the Moon, Hevelius Region. U. S. Geol. Survey Map I-491 (LAC-56).

McCauley, 1968: Preliminary small scale geologic map of the Marius Hills Region in Kaxlstrom, T. N. Vo, et al, Preliminary lunar exploration plan of the Marius Hills Region of the Moon: Astrogeology 5, U. S。 Geol. Survey open-file report, Plate 1. 
Murase, T. and A. Ro McBirney, 1970: Viscosity of lunar lavas. Science, V. 167, pp. 1491-1493。

Murray, J. B。 and Guest, J。 E., 1970: Circularities of craters and related structures on Earth and Moon. Modern Geology, v. I, pp. $149-159$.

Oberbeck, V. R., W. L。 Quaide, and R. Greeley, 1969: On the origin of lunar sinuous rilles。 Modern Geology, v. 1, ppo 75-80.

Ollier, C. D. and M. C. Brown, 1965: Lava caves of Victoria. Bull. Volcanologique, v. 28, pp. 215-229.

Stearns, H. T., 1966: Geology of the State of Hawaii. Pacific Books, Publ. Palo Alto, Calif. 266 p. 
Figure 1. Location of the Marius Hills region and outine of area covered by Lunar Orbiter 5 photography, MR frames

$210-216$

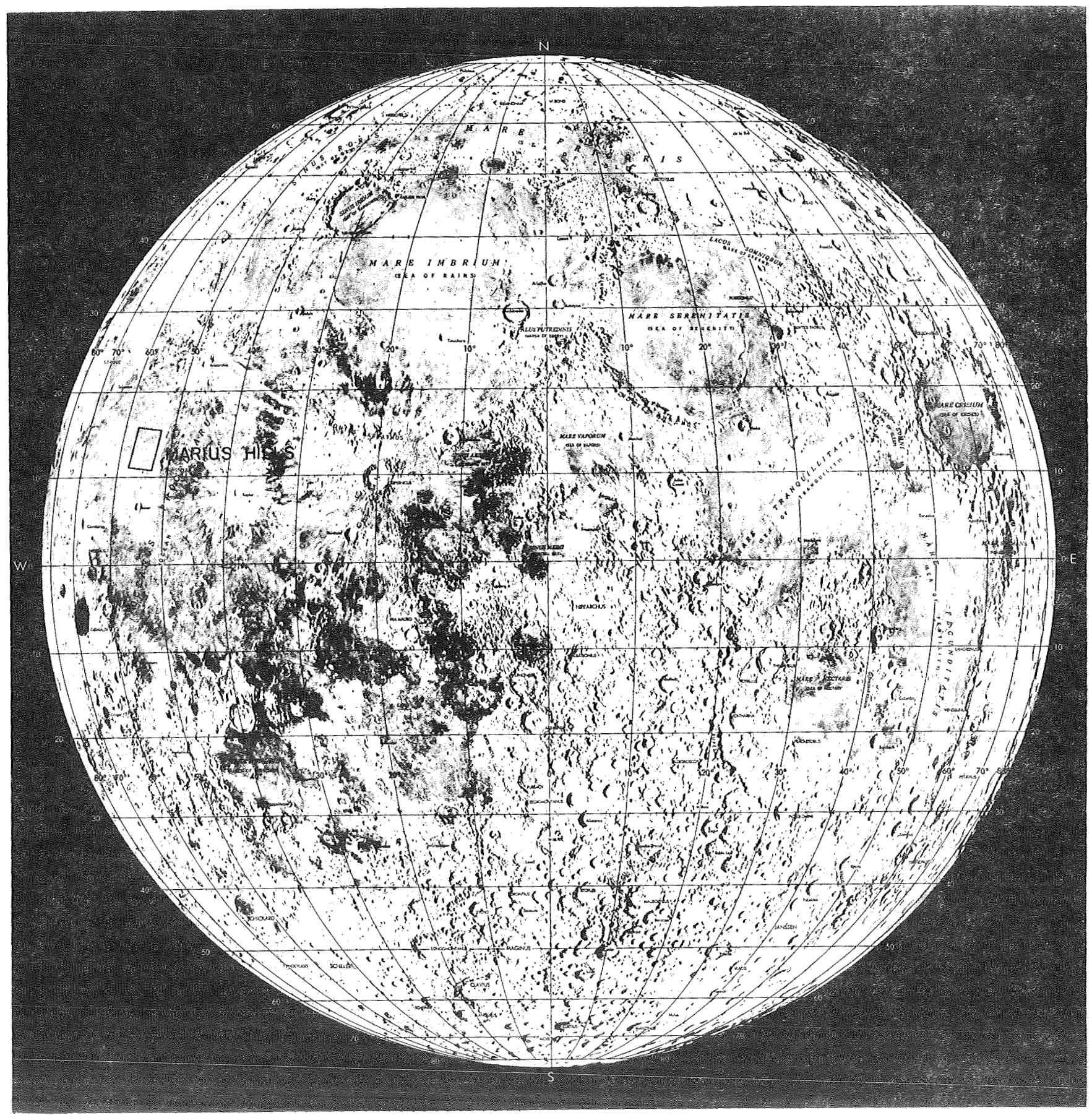


Figure 2. Part of Marius Hills showing rilles and described areas.

Craters described or shown on Figure 3 are identified

by numbers. Location of cross sections (Figure 4 ) are

indicated by letter. Photograph from LO 5 frame MR-213

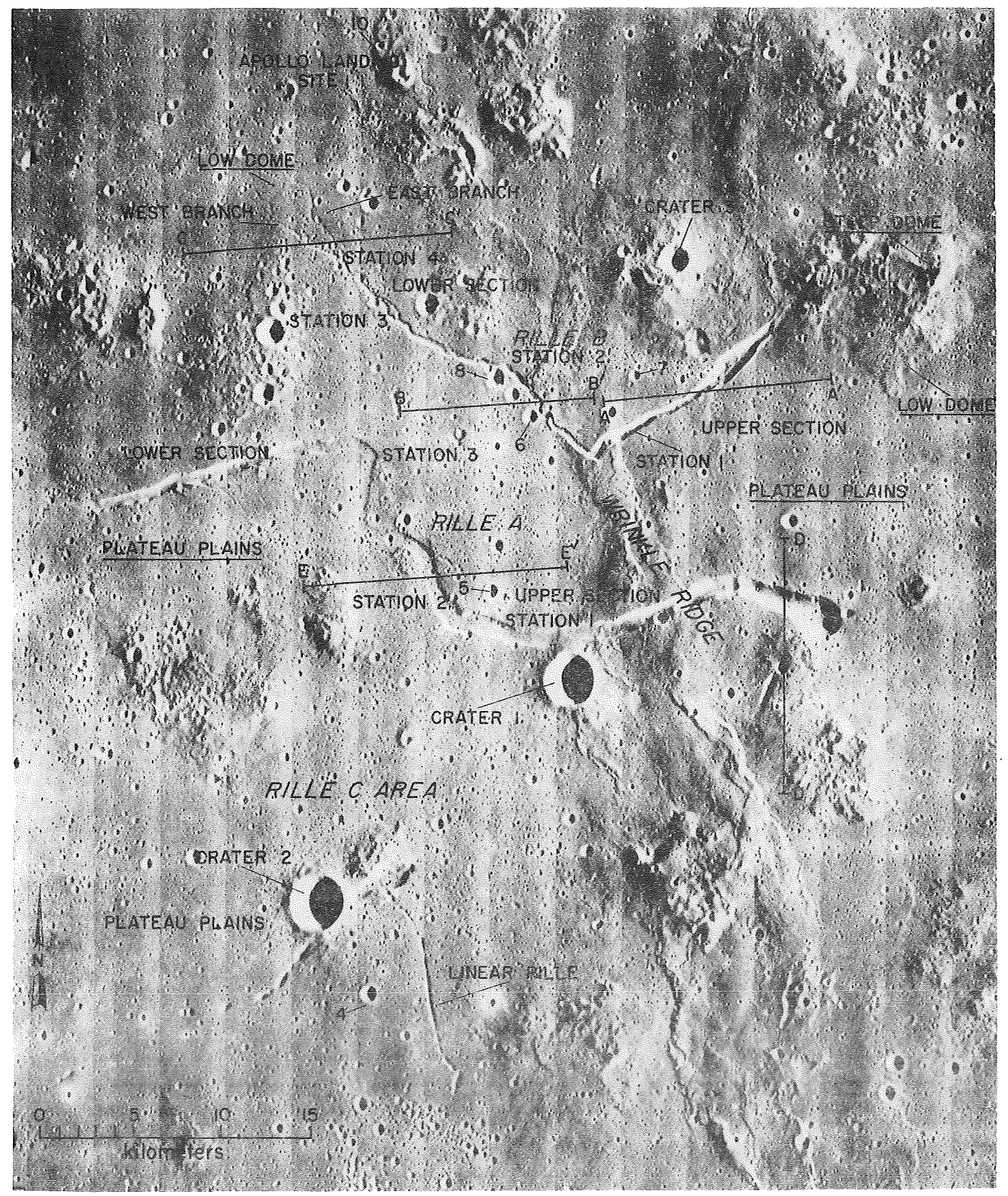


Figure 3. Circularity index (after Murray and Guest, 1970) for terrestrial impact and volcanic craters compared with craters in the Marius Hills. Circularity index of 1.9 generally separates internally and externally produced craters. Data for some terrestrial craters from Murray and Guest (1970). Crater identification: 1-10, Marius Hills (identified in Figure 2); 11, head of Rille A; 12, head of Rille B; 13, head of Rille C; 14, summit crater, Fissure Cone 1; 15, summit crater, Fissure Cone 2; 16, Mauna Loa; 17, Kilauea; 18, Menengai, Kenya;'19, Makaopuhi; 20, Deep Crater, Calif. , 21, Alae; 22, Haiemaumau; 23, Mammoth Crater, Calif. ; 24, Pauialua; 25, Modoc Crater, Calif.; 26, Giant Crater, Calif. ; 27, New Quebec, Canada; 28, Brent, Canada; 29, Holleford, Canada; 30, Meteorite, Arizona; 31, Wolf Creek, Austrailia.

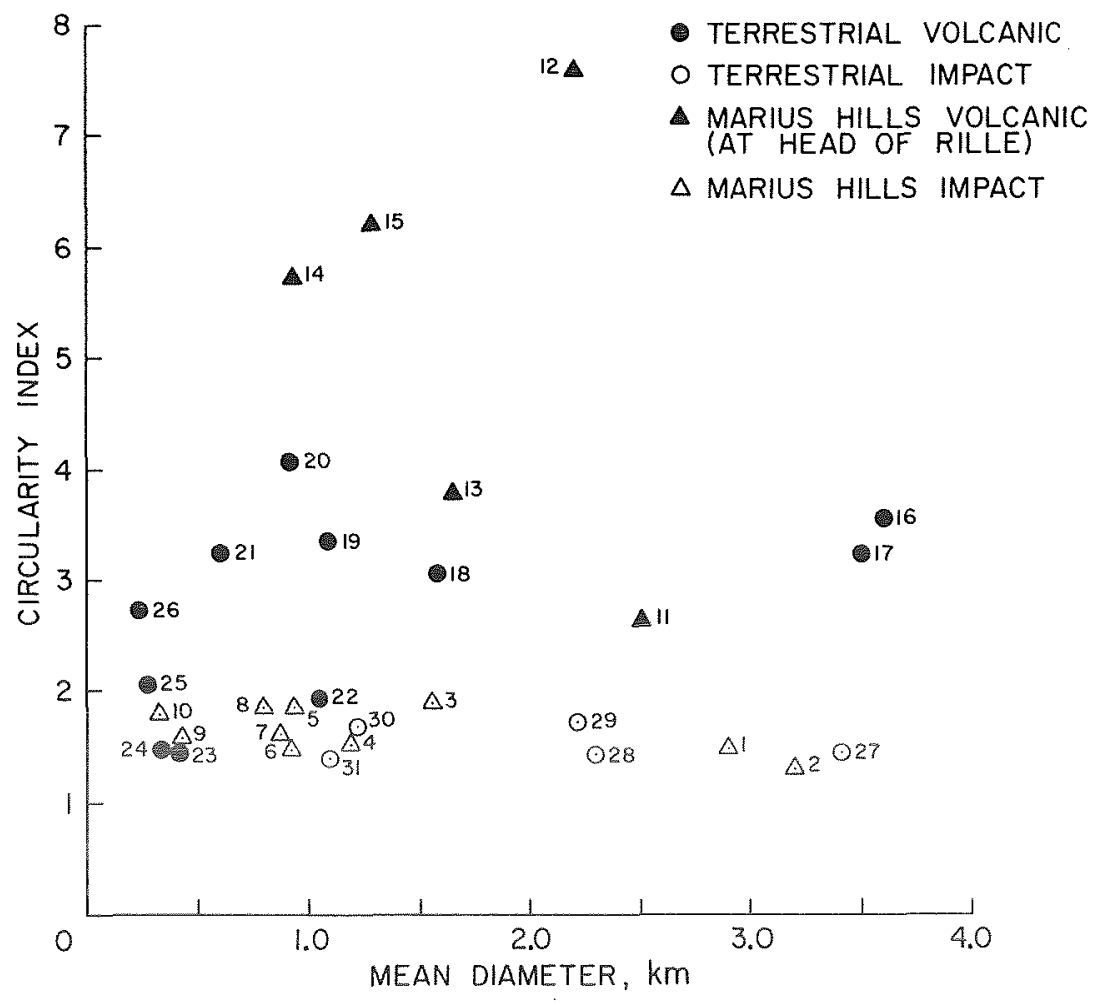


Figure 4. Topographic profile along axes of Rilles A and B; vertical exaggeration X3.5. Topographic control from unpublished TOPOCOM data and from photographic detail.

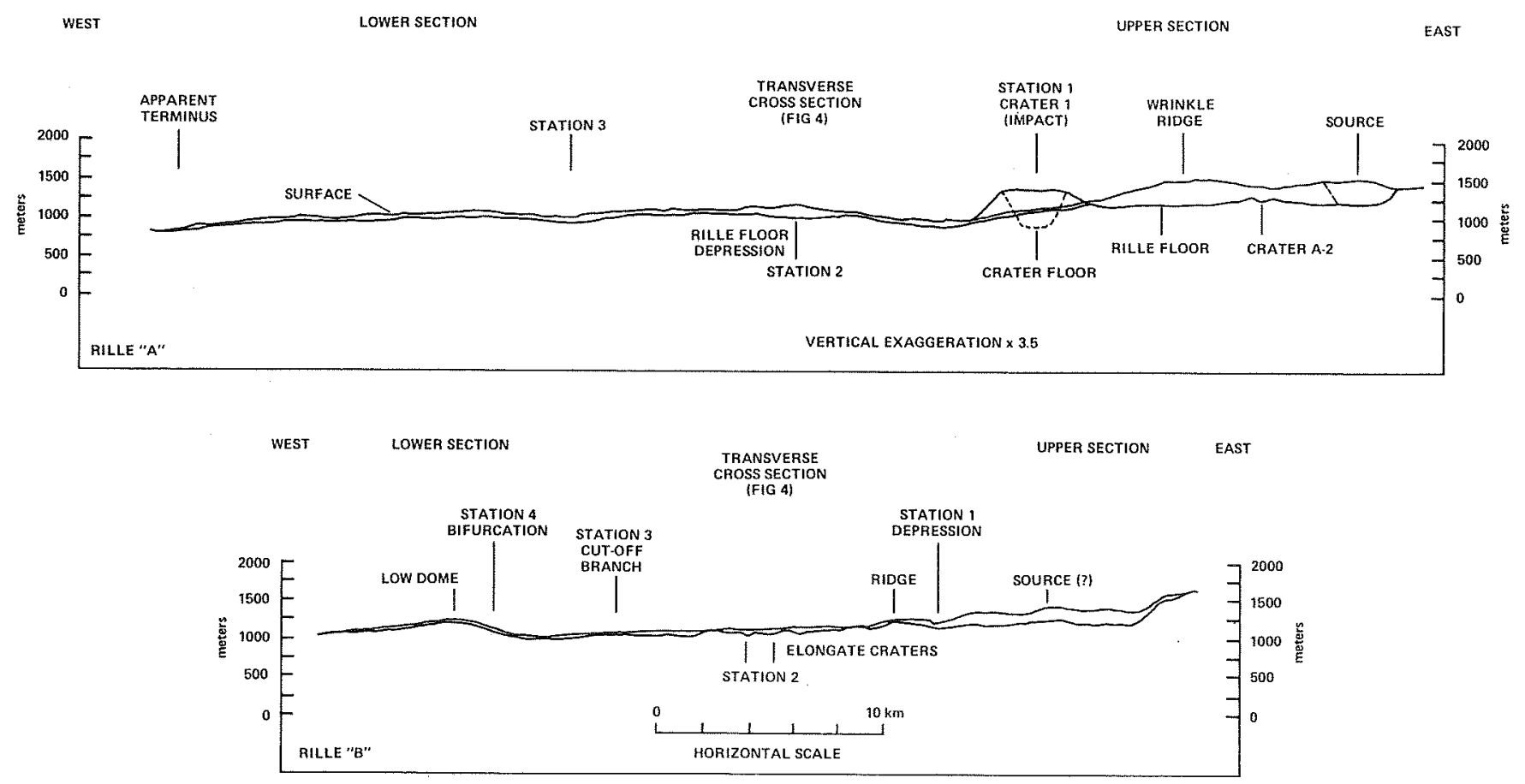


Figure 5. Transverse cross sections for Rilles $A$ and $B$, showing rille on or near a ridge crest and development of levees near the rille source. Topographic control from unpublished TOPOCOM data, photographic detail (rille depths determined from shadow measurements), and from McCauley (1968, section $\left.\mathrm{D}-\mathrm{D}^{t}\right)$.

RILLE "A"

RILLE "B"

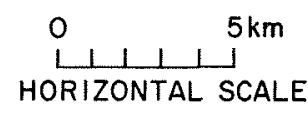

VERTICAL EXAGGERATION $\times 3.5$
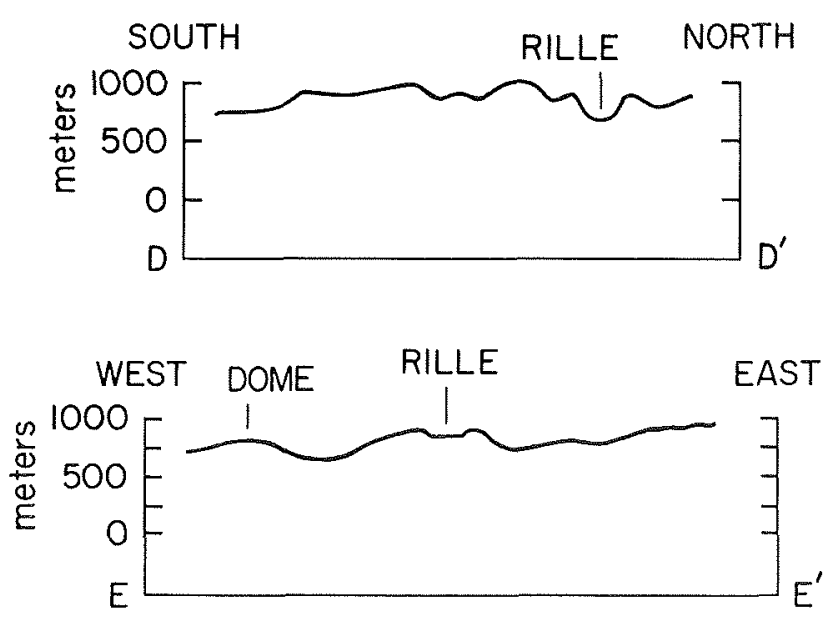
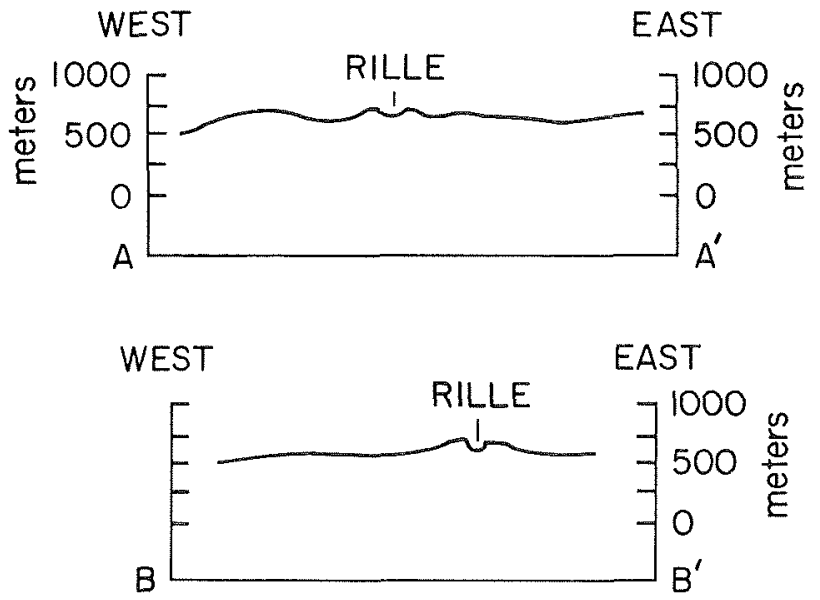

RILLE

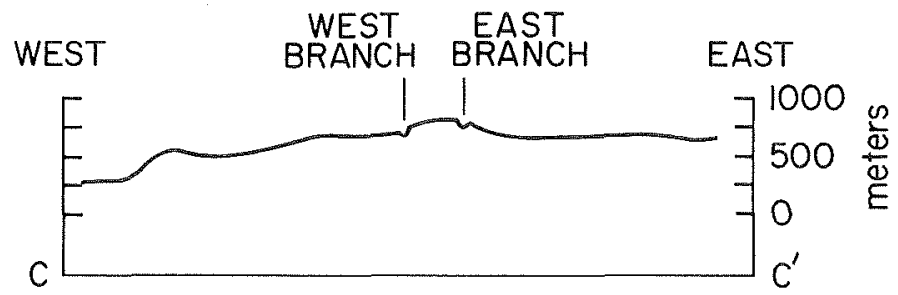


Eigure 6. Rille C area. Crater 2 (circularity index, 1.38, inter-

preted to be impact origin) and its ejecta cover Rilles C and $\mathrm{C}-1 ; 4000 \mathrm{~m}$ contour line from TOPOCOM manuscript map. The upper part of Rille C, originating in Source Crater 13 (circularity index 3.76), is considered a lava channel (compare with Figure 14). Below the ejecta blanket of Crater 2, Rille $\mathrm{C}$ is considered to be a collapsed lava tube. Rille $\mathrm{C}-1$ is discontinuous and is also considered to be a collapsed lava tube, possibly a distributary structure for the main rille. Photograph from LO 5 frame MR-214.

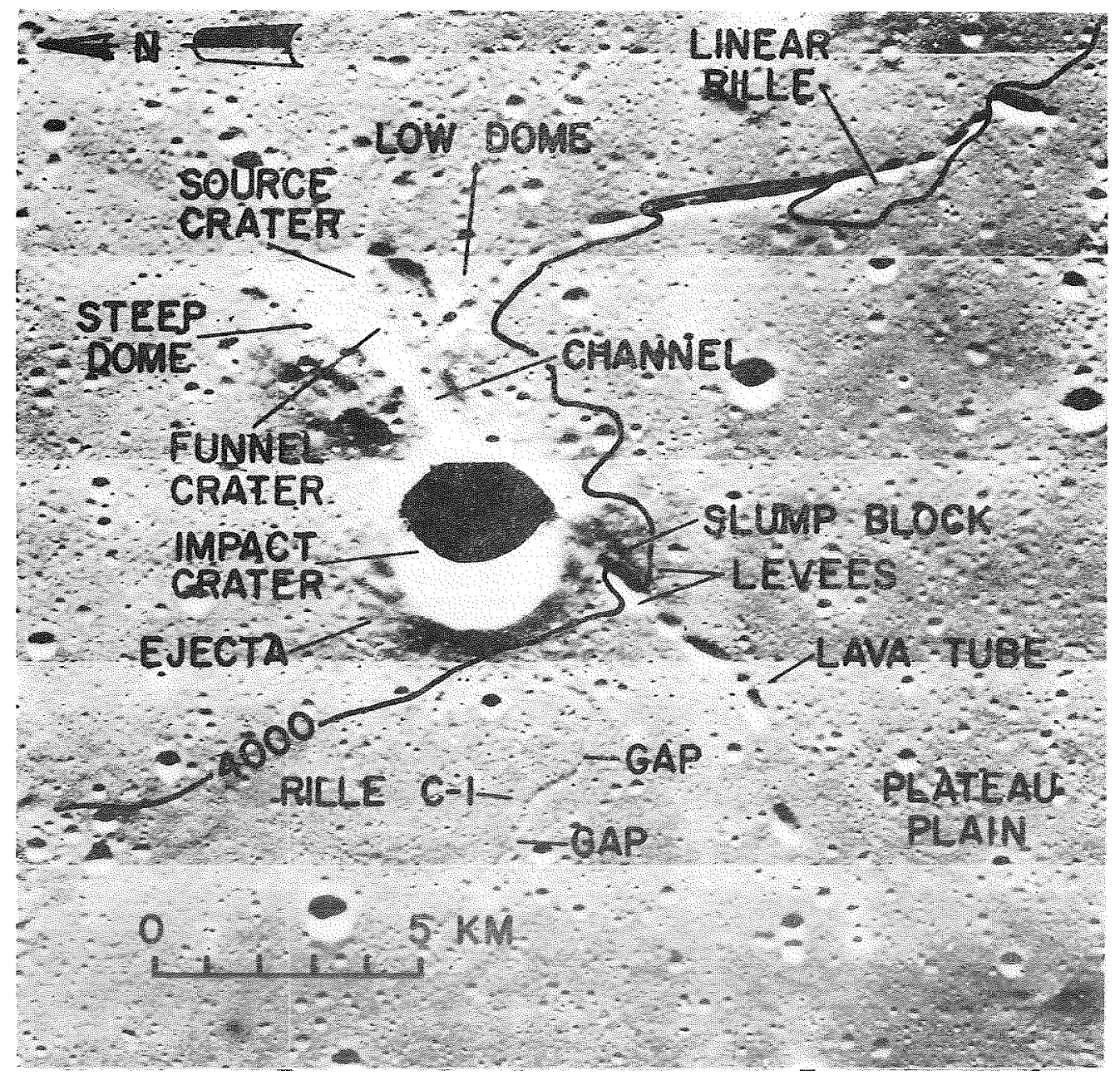


Figure 7. Proposed Apollo landing site. Rille D is interpreted to be either a lava tube or lava channel; Rille $\mathrm{E}$ is considered to be a fracture or fissure; Rille $F$ is interpreted to be a nearly completely collapsed lava tube, probably originating from Fissure Cone 2 (compare with Figure 16). Photograph from LO 5 frames HR-216 and 217.

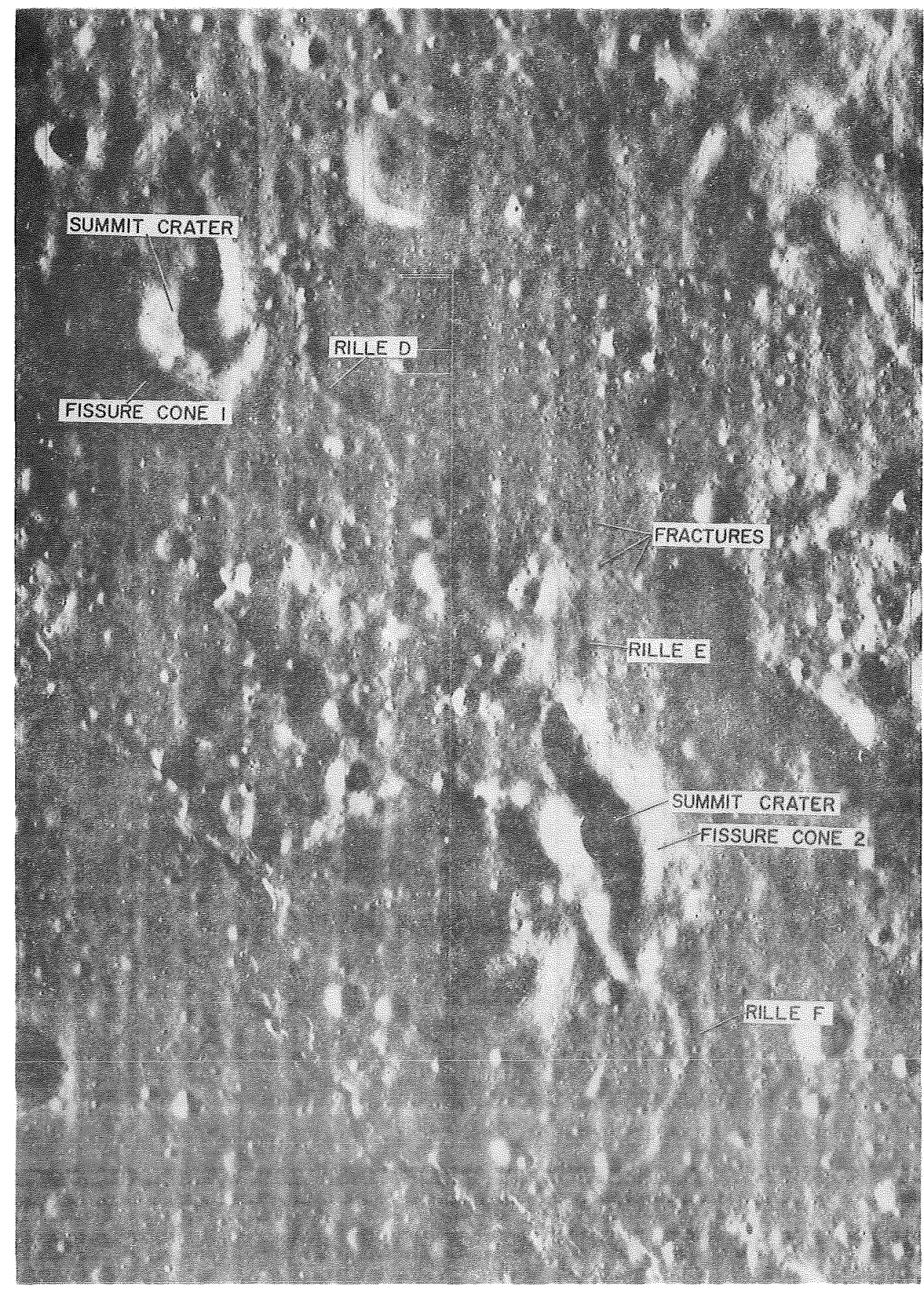


Figure 8. Cross sections along two lava tubes (Annold Irava Tube, Deschutes Co., Oregon, and Modoc Lava Tube, Lava Beds National Monument, Calif.) illustrating formation of topographic high along the tube axis.

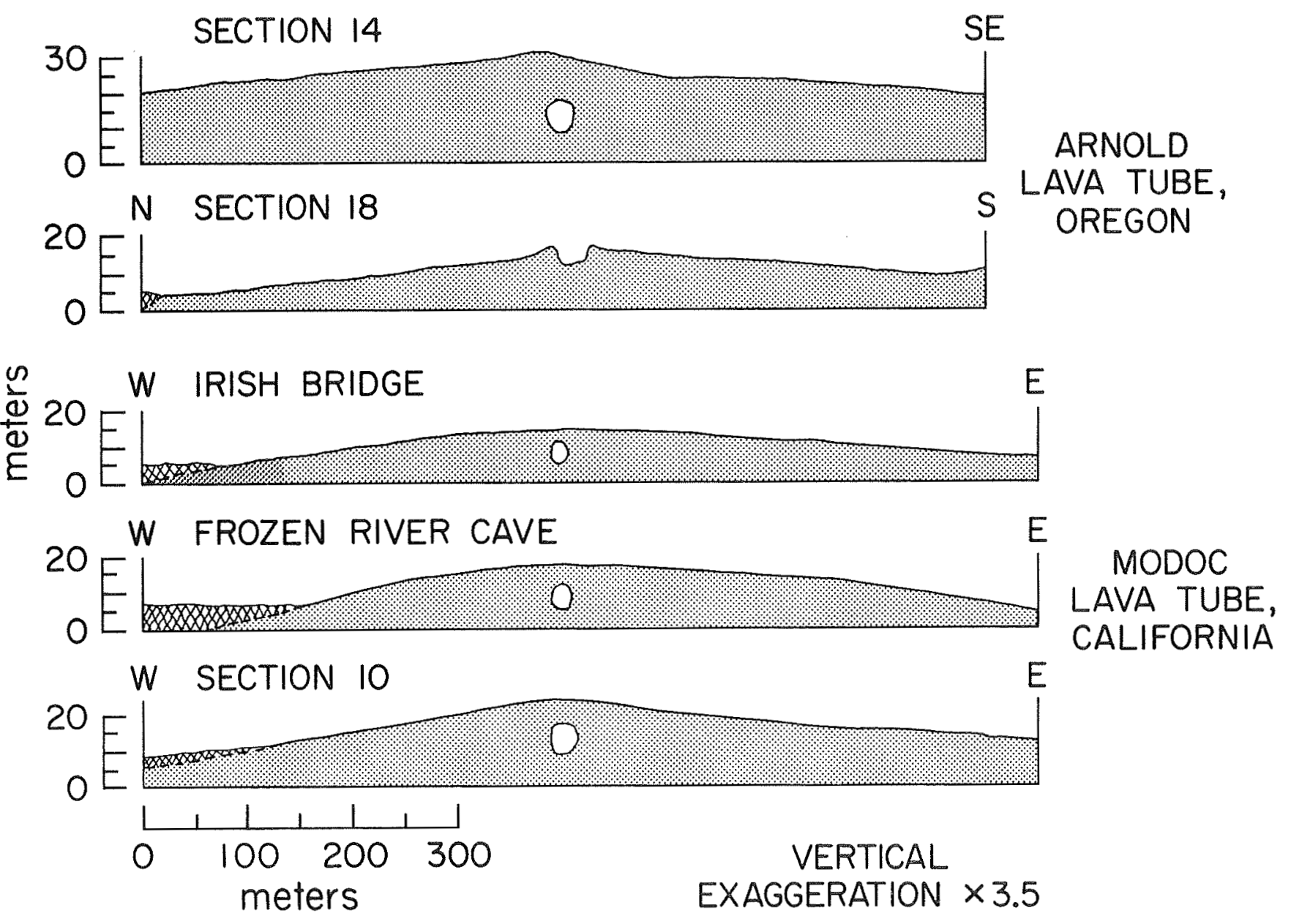


Figure 9. Diagram of uncollapsed part of Prince Albert Cave (lava
tube) in Skamania Co., Washo, illustrating cut off branches.

PRINCE ALBERT CAVE, WASHINGTON

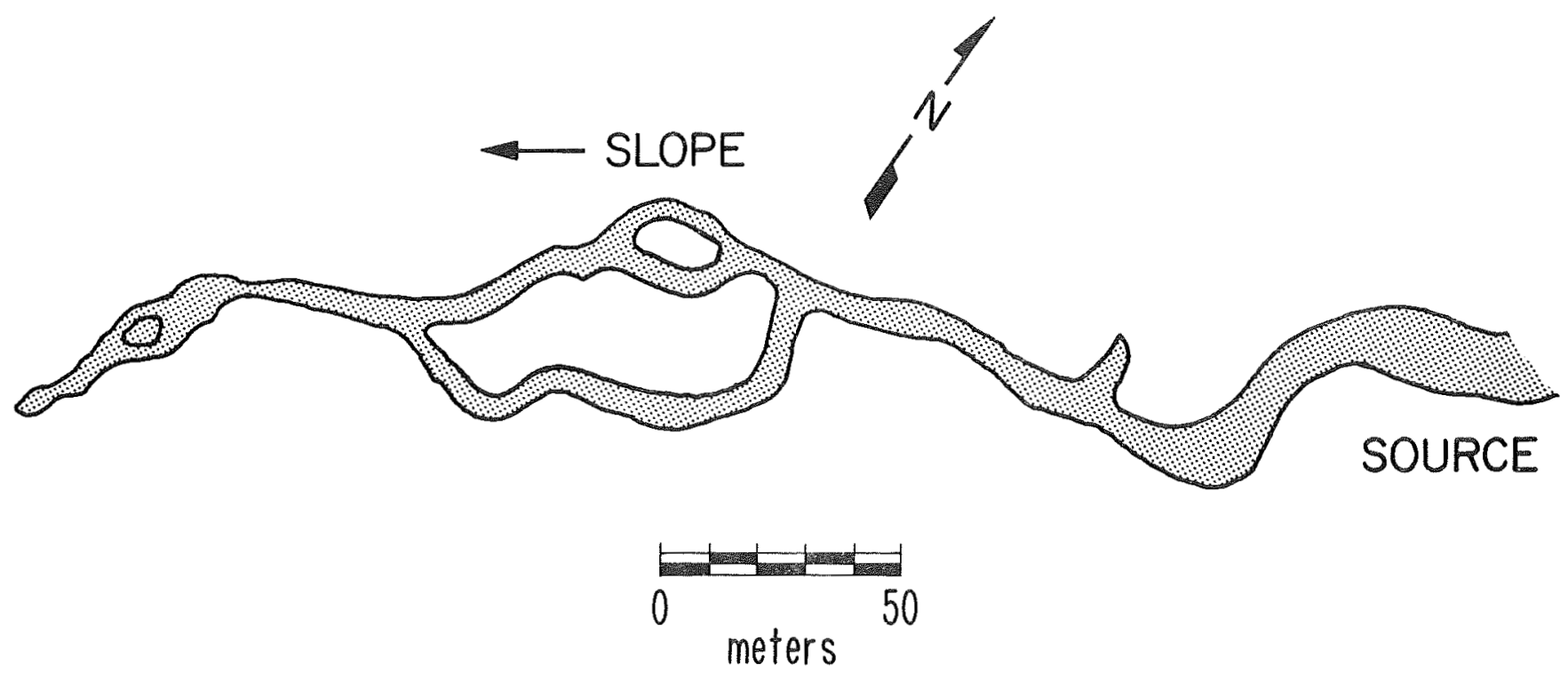


Figure 10. Aerial oblique view of part of Hambone Lava Tube, Siskiyou Co, Calif. Large lateral blocks parallel to the tube have slumped toward the tube, similar to the structure along the collapse depression in Rille $\mathrm{C}$.

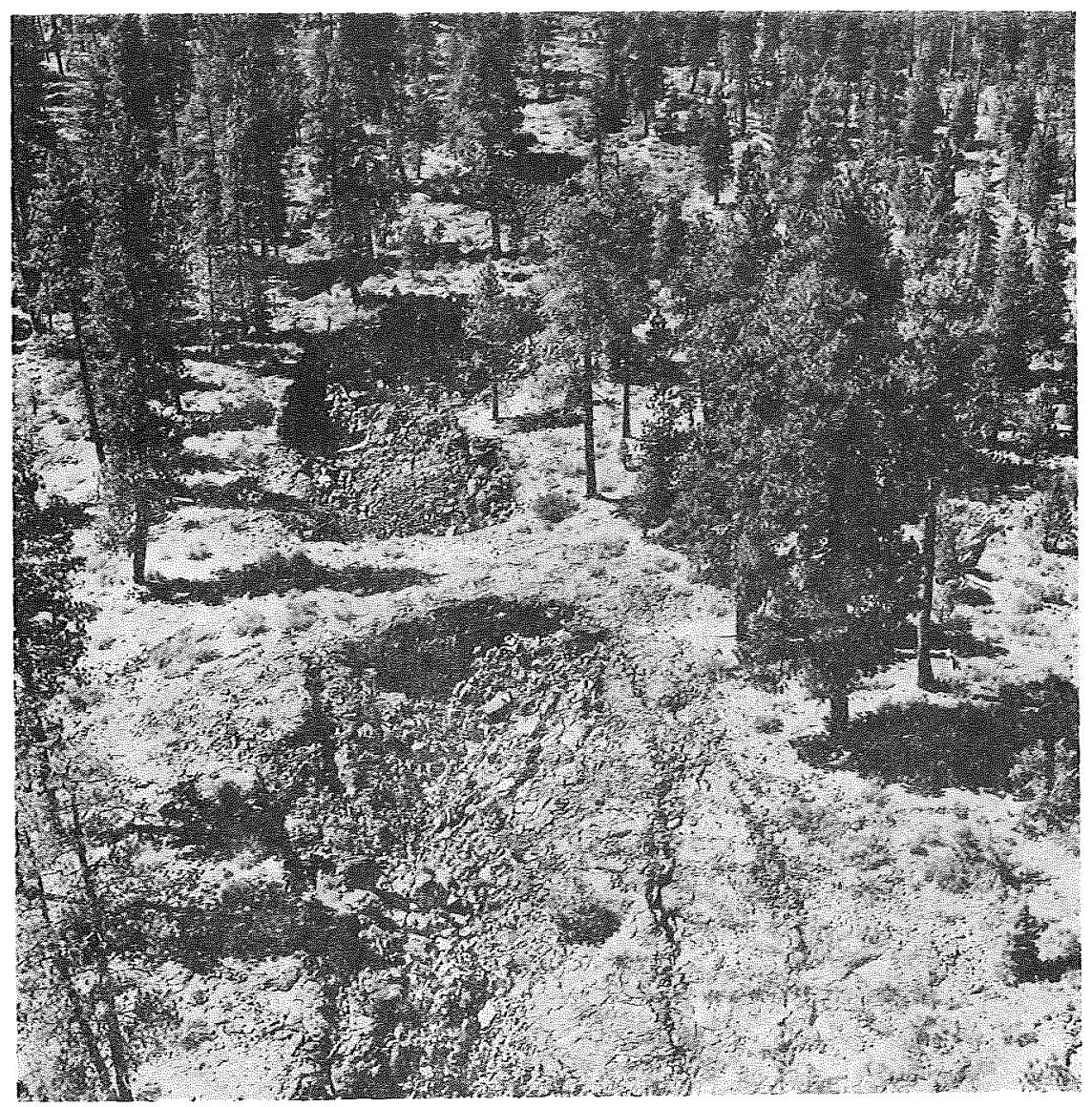


Figure 11. Southwest Rift Zone, Mauna Loa, Hawaii. The rift (A) has controlled the course of the lava channel (B).

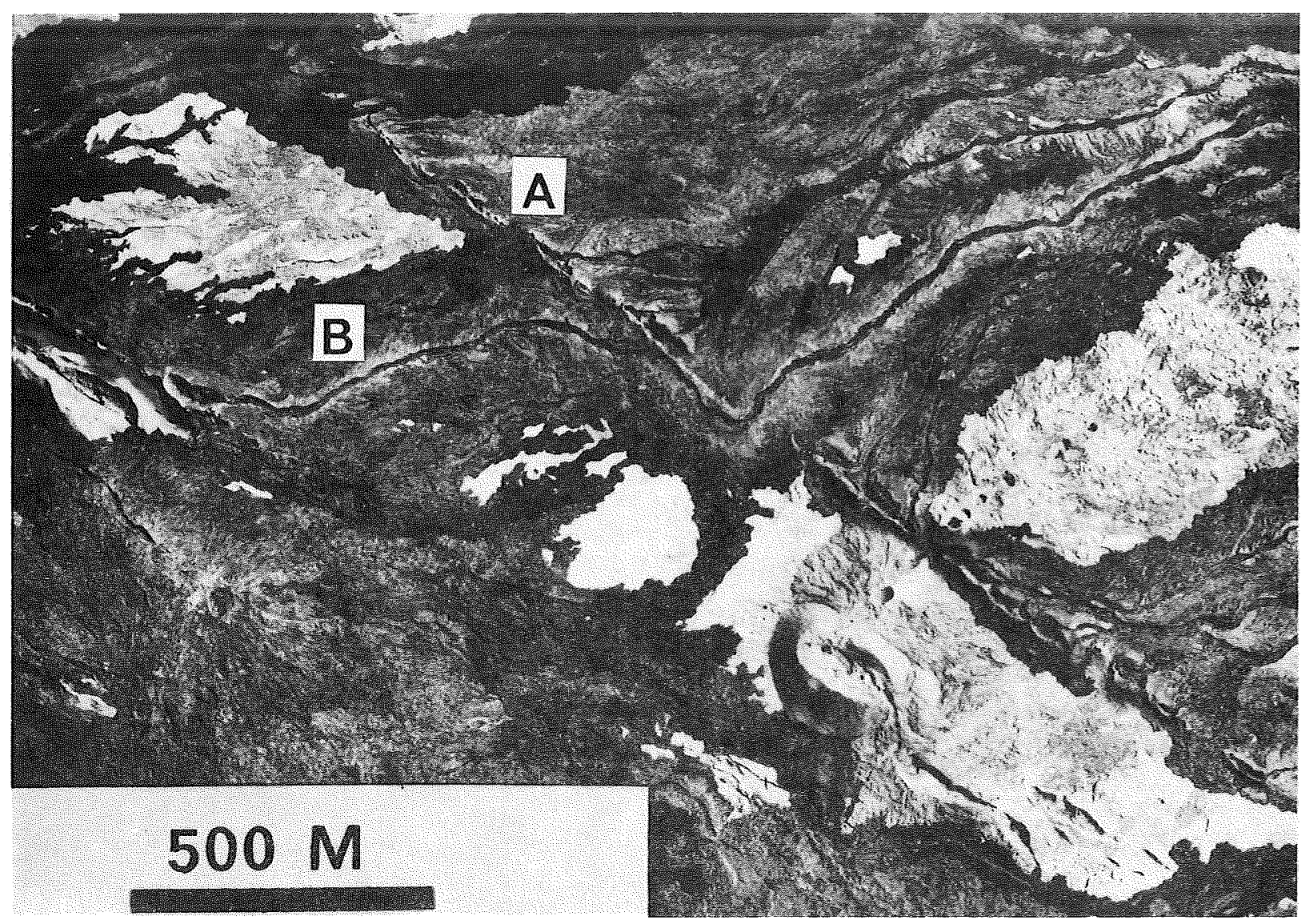


Figure 12. Diagram of a small distributary lava tube system leading from a larger lava channel-tube. Distributary systems deposit lava along major channels and tubes thus elevating the system.

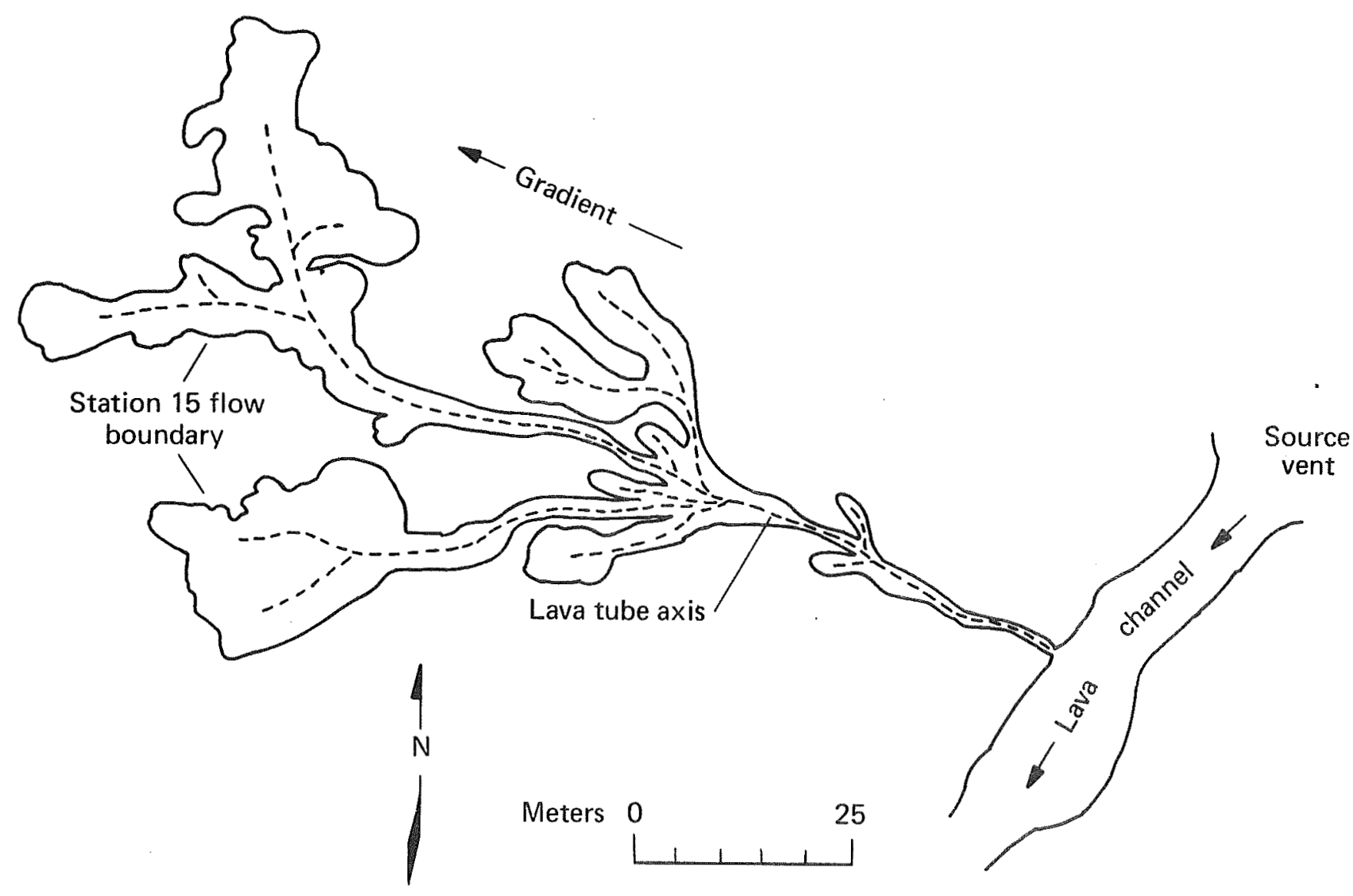


Figure 13. Aerial photograph of Giant Crater and Lava Tube, Siskiyou

Co. Calif. The upper part of the system, near the source

crater, may not have had a free-standing roof after drainage

of the fluid lava, and this may be considered a lava channel.

The lower part of the tube is composed of collapse depres-

sions separated by relatively solid masses of basalt. Giant

Crater has several interior craters which resulted from col-

lapse and drainage of fluids back down the vent.

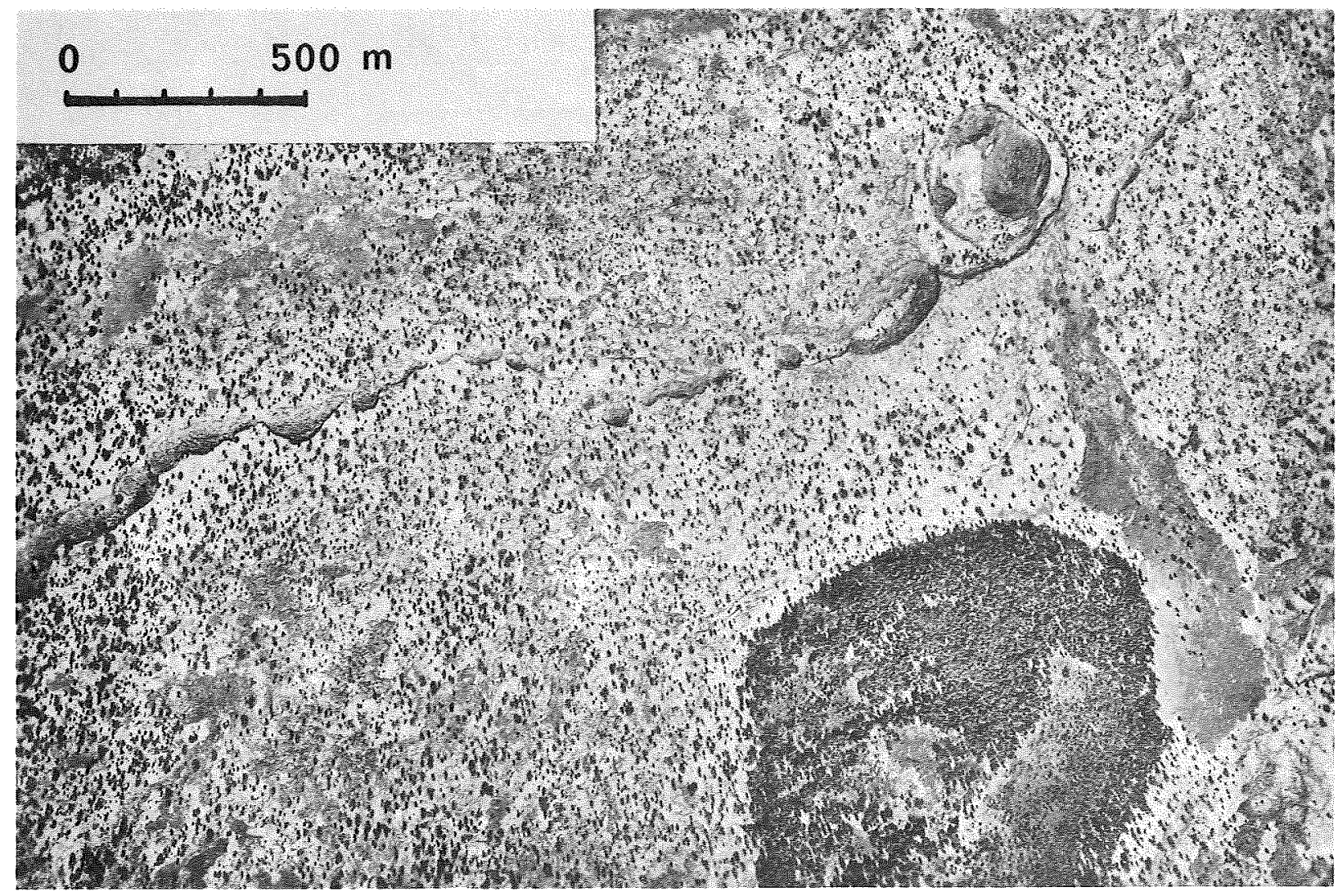


Figure 14。 Mammoth Crater and Lava Tube, Lava Beds National

Monument, Califo The lava tube can be traced through a series of collapse depressions. Like Giant Crater and Tube, Mammoth Crater is adjacent to pyroclastic cones and domes.

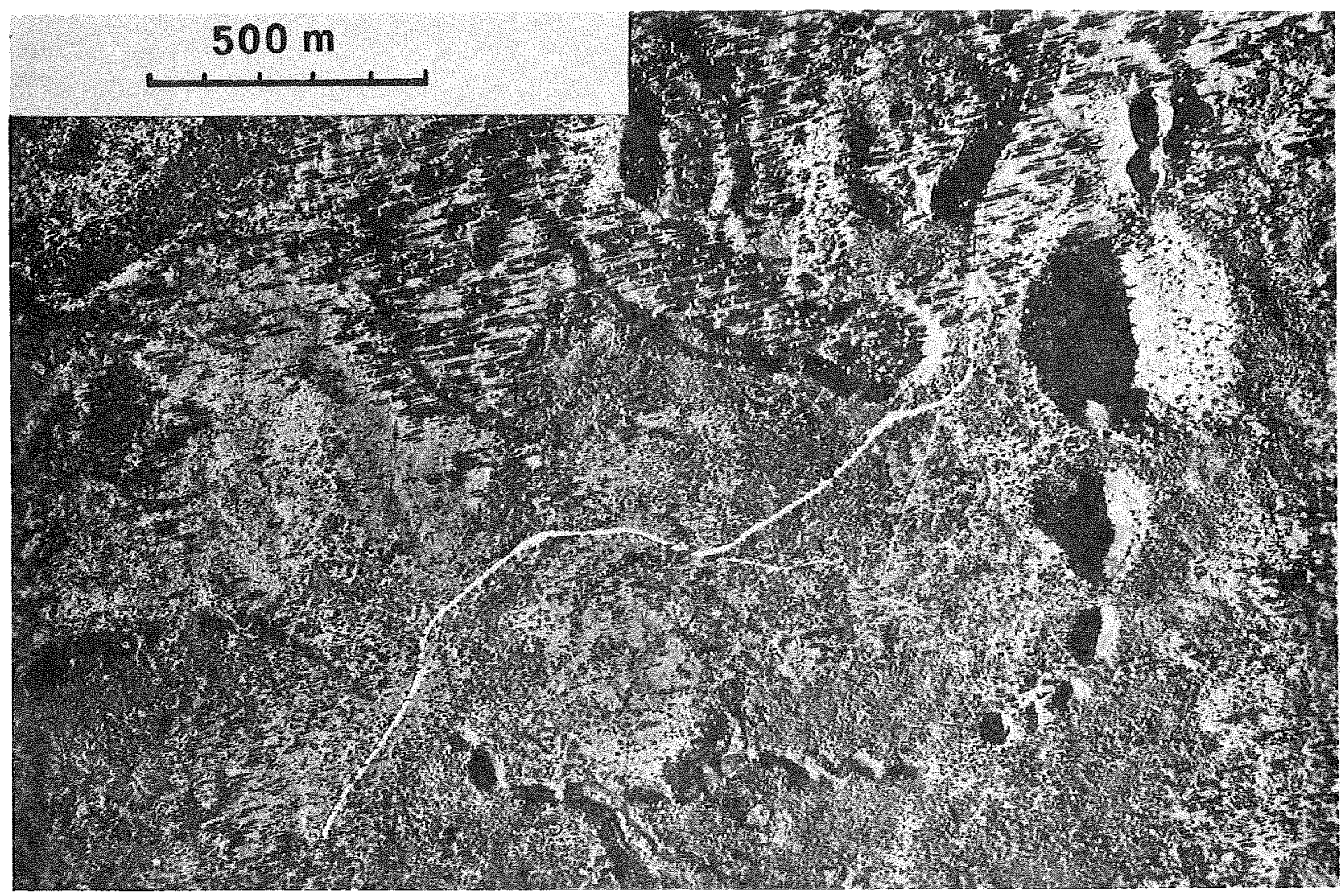


Figure 15. Deep Crater and Lava Tube, Siskiyou Co, Calif. The lava tube originated in or near the crater formed in a pyroclastic cone, then flowed down the flank of the cone onto the lava plains. DeepCrater is approximately $1 \mathrm{~km}$ in diameter. Compare with similar structures in the Proposed Apollo landing site (Figure 7).

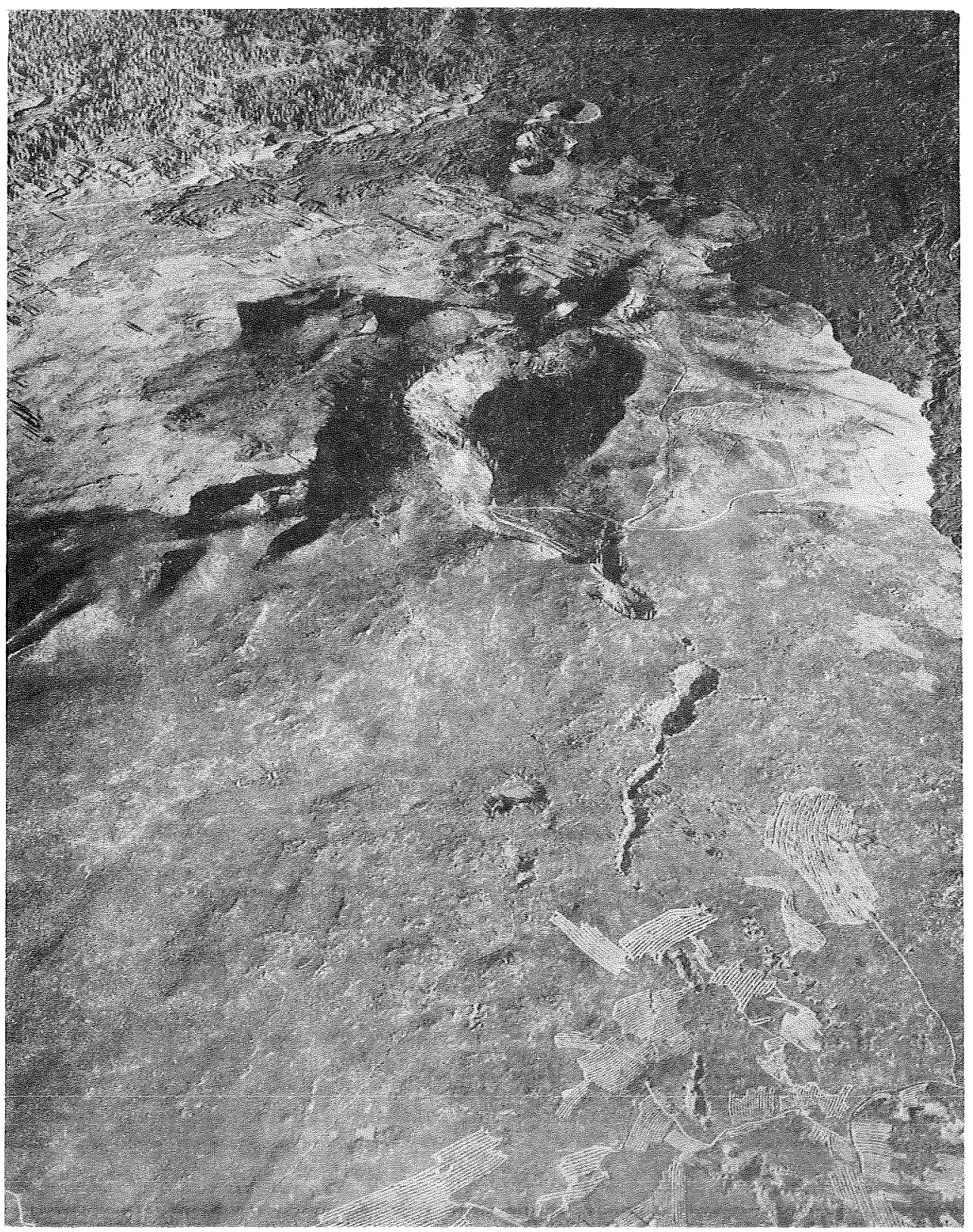


Figure 16. Aerial photographs of part of Modoc Lava Tube and Skull Cave entrance (uncollapsed tube exceeds $27 \mathrm{~m}$ in diameter), Lava Beds National Monument, Calif. Series illustrates the difficulty in detecting cave entrances from the air: 16a-vertical photograph, vertical illumination, ground resolution $37 \mathrm{~cm}$ from altitude of 30,000 ft. ; 16b-vertical photograph, oblique illumination (sun approximately 17 above horizon, similar to Lunar Orbiter photography), ground resolution $29 \mathrm{~cm}$ at altitude of approximately 24, $000 \mathrm{ft}$. ; 16c-oblique aerial photograph, oblique illumination, from altitude of about $200 \mathrm{ft}$. Only in the last photograph, under conditions superior to present lunar imagery, is there any indication of cave entrances. 


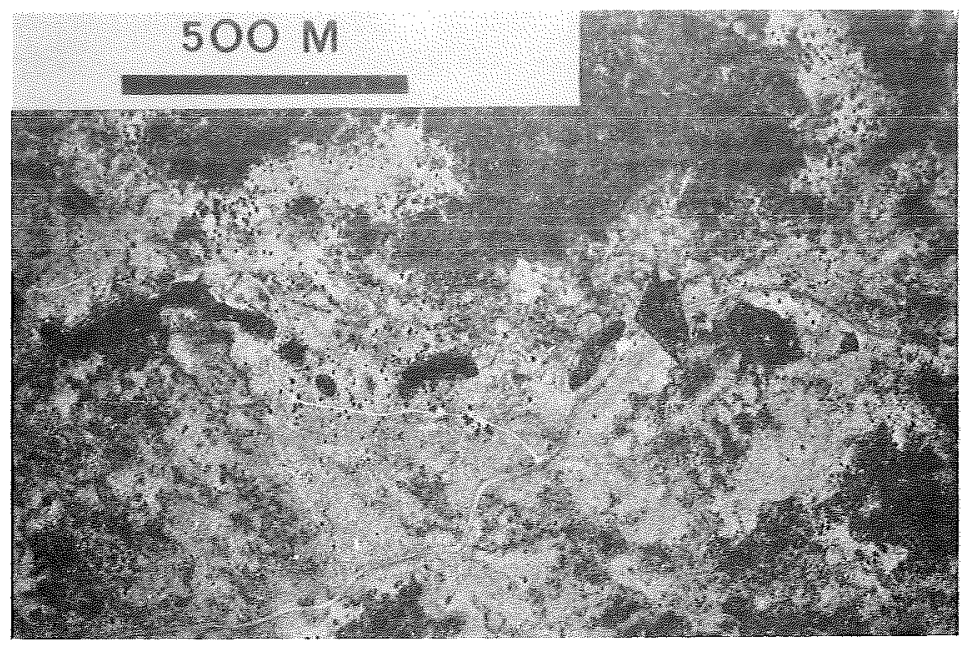

(a)

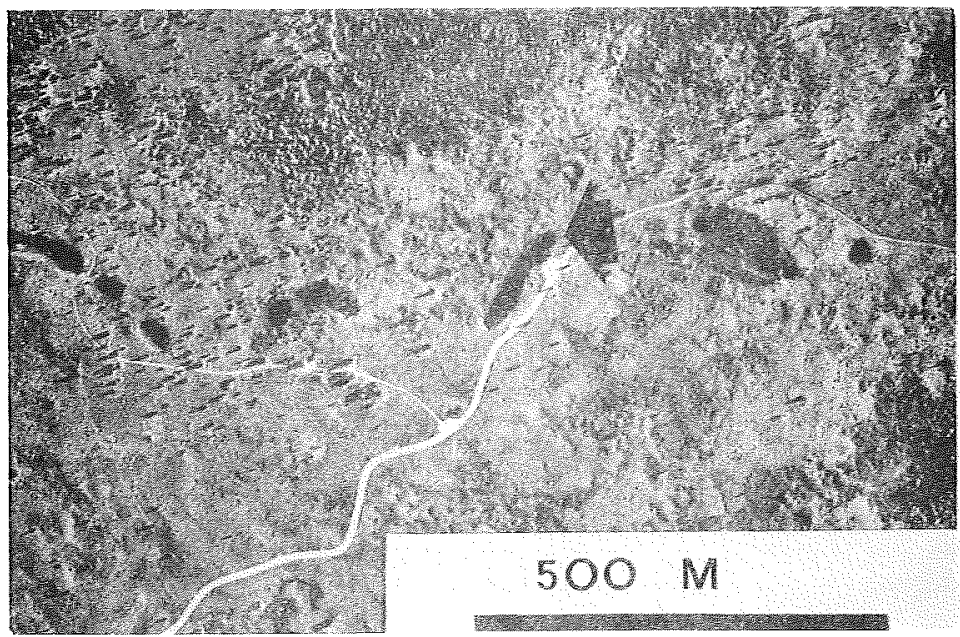

(b)

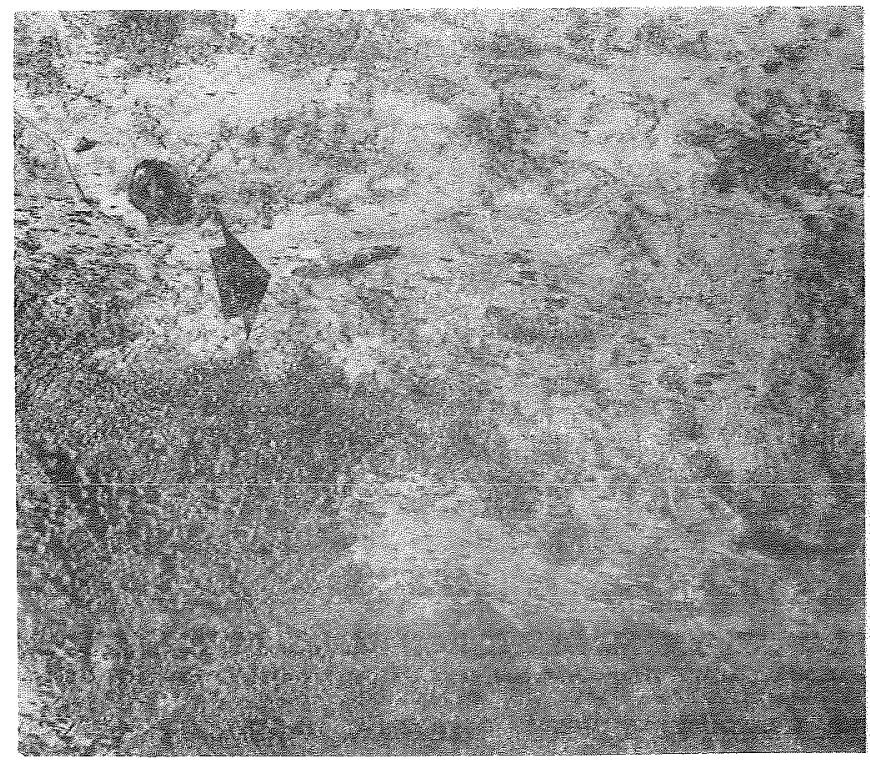

(c) 